\title{
Sedimentology and petrography of the Svenskøya Formation on Hopen, Svalbard: an analogue to sandstone reservoirs in the Realgrunnen Subgroup
}

\author{
Gareth S. Lord ${ }^{1,2}$, Mai Britt E. Mørk', Atle Mørk' \& Snorre Olaussen² \\ 'Department of Geoscience and Petroleum, Institute of Geoscience and Petroleum, Norwegian University of Science and Technology (NTNU), \\ Trondheim, Norway \\ ${ }^{2}$ Department of Arctic Geology, University Centre in Svalbard, Longyearbyen, Norway
}

\begin{abstract}
On the island of Hopen, in the Svalbard Archipelago, the Svenskøya Formation is a succession $35 \mathrm{~m}$ in thickness, consisting primarily of sandstone beds and forming the youngest strata exposed on the island. We present a sedimentological and petrographic study of the formation and compare the unit with its exposures on Wilhelmøya and in Kong Karls Land, Svalbard. We also compare the onshore characteristics of the Svenskøya Formation with those of the Tubåen Formation, its time-equivalent unit in the Sentralbanken area of the northern Barents Sea. On Hopen, the Svenskøya Formation is interpreted as representing coarse clastic sediments deposited in a fluvial to tidal setting, prior to being overlain by a thin interval composed of tidal channel and marine shale deposits. The unit sits atop the regional "Rhaetian Unconformity" and represents sediments deposited during a regressive system that terminates at a flooding surface representing a local transgression of the palaeo-coastline. Petrographic studies show the formation as being arkosic, both on Hopen and in the Sentralbanken area. The reservoir quality of sandstone samples recovered from Hopen is somewhat lower compared to sandstone reservoirs in the Sentralbanken area. We attribute this to greater effects of diagenesis in the Hopen area, which caused increased compaction, mineral dissolution and extensive precipitation of pore-filling clay minerals.
\end{abstract}

\section{Keywords}

Barents Sea; Triassic; Jurassic; exploration; Wilhelmøya Subgroup; petrography

\section{Correspondence}

Gareth S. Lord, Department of Geoscience and Petroleum, Norwegian University of Science and Technology (NTNU), S.P. Andersens veg 15a, NO-7031, Trondheim, Norway.E-mail: gareth.s.lord@gmail.com

\section{Introduction}

Hopen is a small island in the south-east of the Svalbard Archipelago (Fig. la). The elongated island is $32 \mathrm{~km}$ long and $0.5-3 \mathrm{~km}$ wide and features well-exposed strata of Late Triassic age. The outcrops of Hopen have recently been regarded as an excellent analogue to potential reservoir units in the greater Barents Sea area (e.g., Mørk et al. 2013; Klausen \& Mørk 2014; Lord, Solvi, Klausen et al. 2014), resulting in several expeditions to the island. Because of the interest in these rocks as analogues to potential hydrocarbon reservoirs, many expeditions have been completed with support from industry and the Norwegian Petroleum Directorate.

The exposure of the Svenskøya Formation outcropping on Hopen is the primary target of this study. Well-developed deposits of the Svenskøya Formation and the overlying Kongsøya Formation are present at the type sections in Kong Karls Land and on Wilhelmøya (Worsley 1973; Smith et al. 1976; Mørk et al. 1999; Olaussen et al. 2018; Smelror et al. 2018). However, the status of Kong Karls Land as a nature reserve and environmental politics regarding Svalbard have made it difficult for geoscientists to access to Kong Karls Land. The exposures on Hopen and Wilhelmøya are therefore viable alternatives to the type section for those wishing to study the unit.

The Flatsalen and Svenskøya formations on Hopen are time-equivalent onshore analogues to the Fruholmen and Tubåen formations, which are exploration targets in the southern parts of the Norwegian Barents Sea. The recent hydrocarbon discoveries in the Realgrunnen Subgroup in the Hoop area (e.g., the Wisting and Hanssen discoveries [NPD 2018]) have re-established the outcrops 

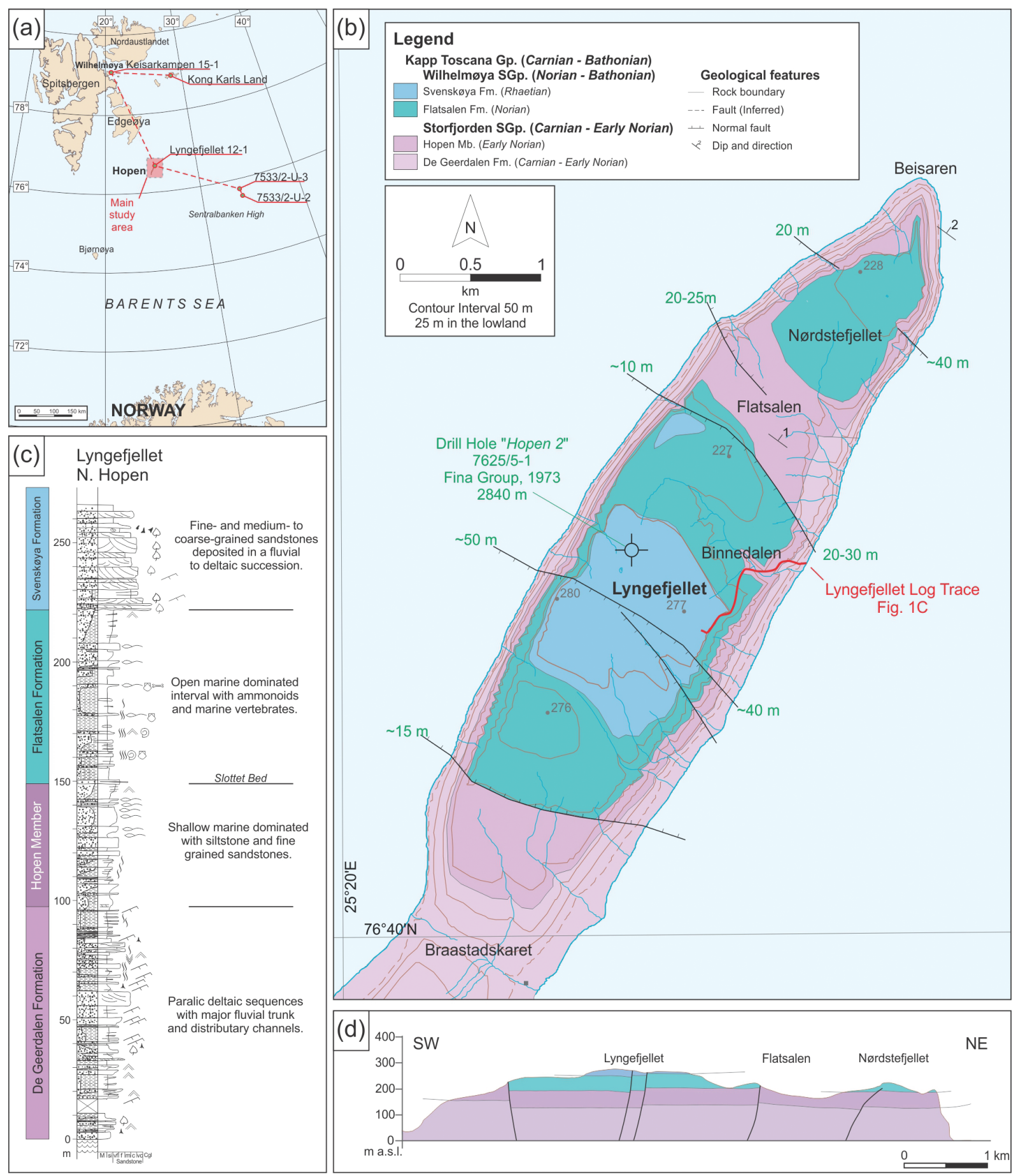

Fig. 1 (a) Map of the Barents Sea, showing the location of Svalbard and the main study area of Hopen in the south-east. Wilhelmøya is also highlighted, as is the position of wells and logged sections presented in this article. (b) Geological map of Hopen modified after Mørk et al. (2013). The log trace for Lyngefjellet (Fig. 1c) is marked by the red line. (c) Log section for the De Geerdalen, Flatsalen and Svenskøya formations at Lyngefjellet, Hopen (after Mørk et al. 2013; Lord, Solvi, Ask et al. 2014). (d) A south-west-north-east orientated cross-section of the summits in northern Hopen modified from Mørk et al. (2013). 
at Hopen as an important analogue. With the exception of palynological dating studies (Smith 1974; Vigran et al. 2014; Patterson \& Mangerud 2015; Patterson et al. 2016), the Svenskøya Formation has received remarkably little attention in recent publications regarding its sedimentary facies and petrography. The bulk of previous work on the Svenskøya Formation on Hopen was conducted by Smith et al. (1975), who described the formation briefly. The underlying Flatsalen Formation, the onshore equivalent to Fruholmen Formation, is well described from Hopen in Smith et al. (1975), Mørk et al. (1999), Mørk et al. (2013), Vigran et al. (2014) and Lord, Solvi, Ask et al. (2014).

The aim of this article is to provide a detailed overview of the Svenskøya Formation on Hopen and, in doing so, it compares the lithostratigraphic, sedimentological and petrographic properties observed on Hopen with localities on Wilhelmøya (290 km north-west), Kong Karls Land (the type section, $230 \mathrm{~km}$ north) and the Sentralbanken area of the Barents Sea (200 km south-east). Petrographic analysis has been performed to determine potential reservoir properties of the unit and this is compared with data from the Sentralbanken area. The article focusses on sandstone-dominated successions in the latest part of the Triassic and Early Jurassic of eastern Svalbard and the northern Barents Sea. Therefore, the Flatsalen Formation, a marine mudstone interval in the region, is outside the scope of this article. Direct comparison of the Svenskøya Formation with specific reservoirs in the Realgrunnen Subgroup from southern areas of the Norwegian Barents Sea is also considered outside the scope of this article.

\section{Geological background}

During the 1960s and the 1970s, the Norwegian Polar Institute (Flood et al. 1971; Worsley 1973), Russian groups (Pčelina 1972) and British expeditions from the Cambridge University Arctic Shelf Programme (Smith 1974; Smith et al. 1975) studied the outcrops on Hopen. Two exploration wells were drilled on the island, operated by Norsk Fina, in 1971 and 1973. The Hopen-1 well (7625/7-1) was drilled in the south-western part of the island, whilst at the Hopen-2 well (7625/5-1) was drilled in the north at Lyngefjellet. The Hopen-2 well penetrates a $1350 \mathrm{~m}$ succession of Triassic age (Harland $\&$ Geddes 1997; Anell et al. 2013) and was spudded in the Svenskøya Formation.

These early studies in the eastern Svalbard area traditionally focused on geological mapping, the chronology of strata and the establishment of lithostratigraphic schemes, as opposed to detailed sedimentological studies. Smith et al. (1975) presented the first overview of the geology on the island of Hopen, establishing a tripartite stratigraphy. The three formations were defined as follows: the Iversenfjellet Formation (now De Geerdalen Formation), the Flatsalen Shale Formation (now simply Flatsalen Formation) and the Lyngefjellet Sandstone Formation (now Svenskøya Formation). In this article, we follow the well-established stratigraphic subdivision of Mørk et al. (1999). An overview of this stratigraphic subdivision is shown in Fig. 2a, with key locations highlighted in red.

Detailed geological data from Hopen were acquired during recent geological mapping expeditions to the island (see Mørk et al. 2013). Several works have focussed on establishing a chronostratigraphic understanding of the older lithological units on Hopen (Lord, Solvi, Ask et al. 2014; Vigran et al. 2014; Paterson \& Mangerud 2015; Paterson et al. 2016). Other studies have focused on the interpretation of sandstone channel bodies, excellently exposed in the Carnian aged De Geerdalen Formation, as analogues to the Snadd Formation in the Barents Sea (Solvi 2013; Klausen \& Mørk 2014; Lord, Solvi, Klausen et al. 2014).

The tectonic regime in south-eastern parts of the Svalbard archipelago is dominated by a series of north-east to south-west trending faults (Grogan et al. 1999; Osmundsen et al. 2014; Anell et al. 2016), which strike parallel to the island of Hopen and down-step from the Edgeøya Platform (Doré 1995; Mørk et al. 2013; Lord, Solvi, Ask et al. 2014; Lord, Solvi, Klausen et al. 2014; Dallmann et al. 2015). Extensional faulting dissects Hopen in a north-west to south-east manner (Fig. lb, d), minor horst and graben structures (Mørk et al. 2013; Osmundsen et al. 2014; Dallmann \& Elvevold 2015). A similar structural trend is observed in seismic lines offshore (Anell et al. 2013; Anell et al. 2016). Fault throws are relatively minor, with the largest being ca. $50 \mathrm{~m}$. Beds dip gently to the north-east (Fig. 1b) and monoclines are also present in the middle and southern areas of the island. Minor anticlinal and synclinal structures with shallow limb dip of 1-2 $2^{\circ}$ (Mørk et al. 2013) are also evident. The area around Hopen has been recognized as one of the focal points for seismic activity in Svalbard, with a cluster of small earthquakes that have been monitored since 1980 (Nasuti et al. 2015). Analysis shows seismic activity to be concentrated along north-west to south-east oriented normal faults.

The stratigraphy of Hopen is dominated entirely by Late Triassic aged rocks of the De Geerdalen, Flatsalen and Svenskøya formations (Figs. 1c, 2). The Carnian to Norian aged De Geerdalen Formation is defined within the Storfjorden Subgroup, whilst the Norian to Rhaetian aged Flatsalen and Svenskøya formations belong to the Wilhelmøya Subgroup in Svalbard. The Wilhelmøya Subgroup was originally defined as a formation by Worsley (1973) and later promoted to a subgroup within the Kapp 

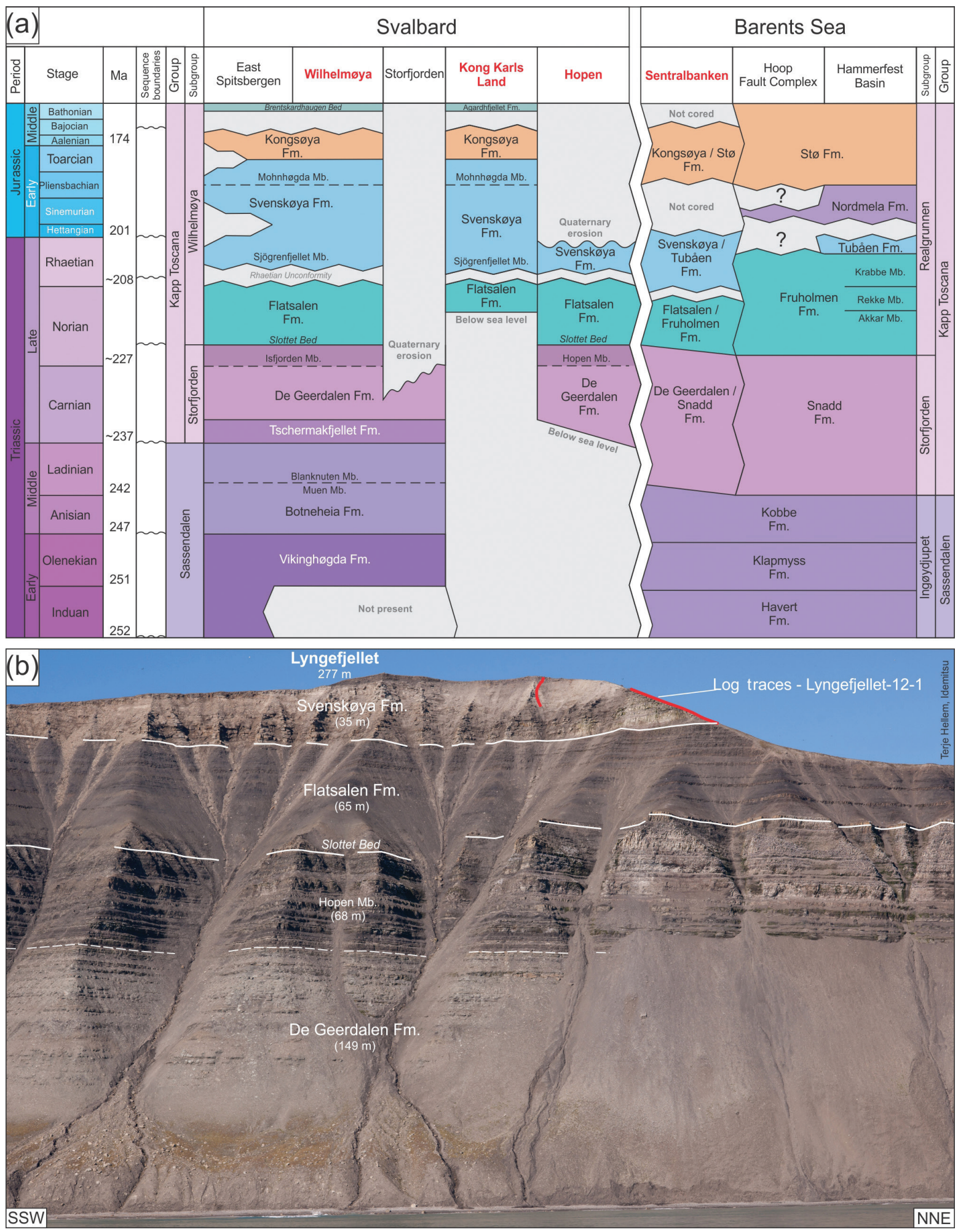

Fig. 2 (a) Modified stratigraphic chart after Mørk et al. (2013) and Lord et al. (2017) showing the relationships between lithostratigraphic units in Svalbard and the Barents Sea. Names of the main locations studied in this article are in red type. (b) A photograph of Lyngefjellet in northern Hopen, showing the distribution of stratigraphic units. The log trace for Lyngefjellet-12-1 (Fig. 4) is marked in red. Note that formation thicknesses are based on log measurements from several localities on Hopen. 
Toscana Group by Mørk et al. (1999). The Realgrunnen Subgroup is the offshore equivalent to the Wilhelmøya Subgroup, and this terminology is used throughout the Norwegian Barents Sea, an area where the unit has proven to be a prolific reservoir interval (Henriksen et al. 2011; Lundschien et al. 2014).

A complete section of the Wilhelmøya Subgroup (Worsley 1973; Mørk et al. 1982; Mørk et al. 1999) is present on Wilhelmøya, with the locality at Keisarkampen being defined as the type section (Mørk et al. 1999). The Svenskøya Formation, however, is only partially exposed, as it consists of poorly consolidated sandstone beds with good exposure being limited to a few sparse outcrops. Unconsolidated or poorly consolidated sandstone is typical for the Svenskøya Formation and this is also the case for the type section in Kong Karls Land. Hopen is unique in this regard, as the exposures are significantly better consolidated because of deeper maximum burial, as indicated in the regional study by Henriksen et al. (2011).

Ammonoid biostratigraphy, palynology and magnetostratigraphy provide a Carnian to early Norian age for the De Geerdalen Formation (Tozer \& Parker 1968; Pčelina 1972; Korčinskaja 1980; Launis et al. 2014; Lord, Solvi, Ask et al. 2014; Vigran et al. 2014; Paterson \& Mangerud 2015; Paterson et al. 2016). The De Geerdalen Formation and its offshore counterpart, the Snadd Formation, represent paralic deltaic facies, deposited in a shallow epicontinental sea (Mørk et al. 1982; Riis et al. 2008; Glørstad-Clark et al. 2010; Høy \& Lundschien 2011; Lundschien et al. 2014).

The Flatsalen Formation (Fig. 2) has a prominent (ca. $2 \mathrm{~m}$ thick) bioclastic carbonate bed at its base: the Slottet Bed (Mørk et al. 1999; Mørk et al. 2013). The bed is composed of fine- to medium-grained carbonaceous sandstone, containing bivalve and ammonoid fossils with abundant phosphatic nodules. Gravel beds and lithic clasts are also found. The Slottet Bed represents condensed shelf deposits (Mørk et al. 1999) and is often described as a "transgressive lag" (Klausen \& Mørk 2014; Lord, Solvi, Ask et al. 2014; Lord, Solvi, Klausen et al. 2014).

The overlying rocks consist of dark marine shales with minor coarsening-upward successions grading into thin beds of siltstone and very fine-grained sandstone. The unit is dated as Norian in age primarily based on ammonoid biostratigraphy, magnetostratigraphy (Pčelina 1972; Korčinskaja 1980; Lord, Solvi, Ask et al. 2014) and palynology (Vigran et al. 2014; Paterson \& Mangerud 2015; Paterson et al. 2016). The type section for this unit is defined on Hopen (Mørk et al. 1999) and its name originates from a topographic saddle mountain in the north of the island.

The Flatsalen Formation (Fig. 1c) marks the onset of a major marine transgression in the eastern areas of Svalbard and the Arctic during the early Norian age (Mørk \&
Smelror 2001; Klausen \& Mørk 2014). The overall coarsening upwards trend of the Flatsalen Formation-from open marine shale deposits to heterolithic beds composed of siltstone and sandstone-likely represents deposition in a prodelta environment that preceded the deposition of the Svenskøya Formation.

The boundary between the Flatsalen Formation and the overlying Svenskøya Formation (Fig. 1c) is marked by an erosive contact. This is a key sequence stratigraphic surface in Svalbard and the Barents Sea (Gjelberg et al. 1987) and is comparable to the "Rhaetian Unconformity" as defined by Embry (2011) in the Sverdrup Basin of Arctic Canada. The unconformity coincides with the development of the Novaya Zemlya Fold and Thrust Belt (Drachev 2016; Faleide et al. 2017). The cliff-forming, white and grey sandstone beds (Fig. 3) represent an extension of the Svenskøya Formation, as defined in Kong Karls Land (Mørk et al. 1999). The formation is correlative to the upper part of the Fruholmen and Tubåen formations of the Realgrunnen Subgroup (Worsley et al. 1988; Mørk et al. 1999), although it is not necessarily the chronostratigraphic equivalent.

Earlier work by Smith et al. (1975) described the Svenskøya Formation on Hopen as being correlative to the Tumlingodden member of the Wilhelmøya Formation as defined by Worsley (1973). Here, the Svenskøya Formation is described briefly as a cliff-forming sandstone that is weathering white and appears quartz rich. The main part of the cliff was described as massive, crossstratified sandstones in the middle part, with plant fragments and thinner bedded sandstones at the top and base of the unit. The upper sandstone beds were observed as being thinly bedded, within silty shales. Sandstones initially described as being the lower part of the Svenskøya Formation by Smith et al. (1975) are now regarded as the uppermost part of the Flatsalen Formation and represent prodelta deposits. The Svenskøya Formation was defined as being fluvial in origin by Smith et al. (1975).

During revision of the Mesozoic stratigraphic nomenclature in Svalbard, Mørk et al. (1999) extended the definition of the Svenskøya Formation from the island of Svenskøya in Kong Karls Land to Hopen and Wilhelmøya (Figs. 1a, 2a). The Flatsalen Formation was maintained, whilst the Iversenfjellet and Lyngefjellet Sandstone formations of Smith et al. (1975) were included in the De Geerdalen and Svenskøya formations, as elsewhere on Svalbard.

On Hopen, the Svenskøya Formation is now regarded as Rhaetian in age, although this dating is still regarded as somewhat tentative on account of the lack of sufficient biostratigraphic evidence (Paterson \& Mangerud 2015; Paterson et al. 2016). Palynological studies by Smith et al. (1975) regarded the Svenskøya Formation as Jurassic in 


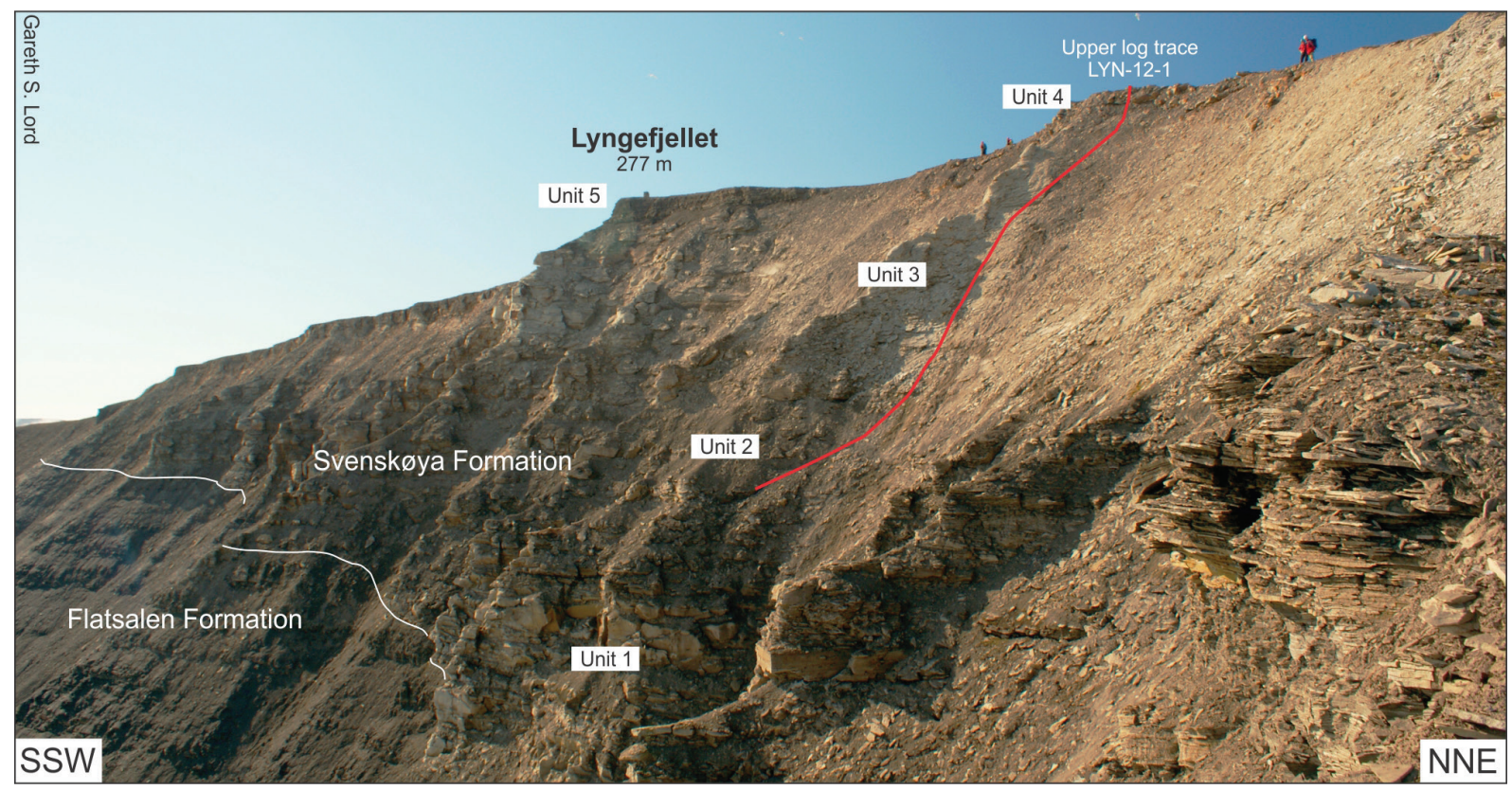

Fig. 3 Photograph of the Svenskøya Formation at Lyngefjellet, geologists at the top of mountain for scale. Red line marks the log trace for the upper part of Lyngefjellet 12-1 accessible with rope; the lower part of the log is out of view. Note the visual changes from darker sandstone packages in the base to more greyish-yellow sandstone beds in the upper part. The darker beds of siltstone and sandstone are visible at the summit. The subdivision of the succession into the five informal units is also shown.

age, with the upper part of the De Geerdalen Formation and Flatsalen Formation being dated as being of Rhaetian age. Rocks of Rhaetian age have not been conclusively dated in Svalbard previously. Herein, however, we follow the ages presented by Paterson \& Mangerud (2015) and Paterson et al. (2016).

During the Neogene, Hopen (and Svalbard as a whole) experienced a severe uplift, glacial bound-rebound and erosion (Throndsen 1982; Dimakis et al. 1998; Henriksen et al. 2011). Estimates by Henriksen et al. (2011) suggest a net erosion of 2.2 to $2.3 \mathrm{~km}$ in the Hopen area, whilst the wells in the Sentralbanken High likely experienced a less than 1.5-km erosion. However, the general trend of increased westward palaeo-temperature (Senger 2017) might influence those estimates. Previous deeper burial has likely influenced both mechanical and chemical compaction of the Svenskøya Formation.

\section{Methods}

The Svenskøya Formation on Hopen was studied in detail during mapping expeditions and petroleum license excursions from 2009 to 2013, organized by SINTEF Petroleum AS and the Norwegian Petroleum Directorate. The Lyngefjellet section (Fig. 3) features the most complete exposure of the Flatsalen and Svenskøya formations on the island. The transition from the Flatsalen Formation and the lower part of the Svenskøya Formation can be seen and easily accessed along the eastern ridge of Lyngefjellet (Figs. 2b, 3).

Sedimentological sections were measured at the Lyngefjellet locality (Lyngefjellet 12-1), at a scale of 1:50 in the field. In addition, sedimentological sections measured at Wilhelmøya (Keisarkampen 15-1) and Kong Karls Land are also included for regional, onshore comparison. Cores from the 7533/2-U-2 and 7533/2-U-3 wells, drilled by the Norwegian Petroleum Directorate in the Sentralbanken area, were measured in detail at the directorate's core store in Stavanger and are included to create an offshore link.

Samples for both petrography and palynology were collected from the field and core laboratory. Finegrained samples for palynological dating were presented by Paterson \& Mangerud (2015) and Paterson et al. (2016). Thin sections were produced with blue dye to indicate porosity. Contemporary optical microscopy studies and scanning electron microscopy analysis were employed to study the mineral, cement and porosity content. Point counting of each sample (300 points) was also conducted to quantify the grain composition. Petrographic data from the 7533/2-U-2 well were also included in this article to aid the discussion regarding 
the petrographic development of the Svenskøya Formation southwards into the Barents Sea and to support a regional onshore-offshore link.

\section{The Svenskøya Formation in eastern Svalbard}

\section{Hopen}

On Hopen, the Svenskøya Formation unconformably overlies the Flatsalen Formation at the "Rhaetian Unconformity". The Flatsalen Formation at Lyngefjellet is $75 \mathrm{~m}$ thick and well exposed. The Slottet Bed (Fig. 1c) is ca. $2 \mathrm{~m}$ thick on Hopen and is composed of bioclastic, carbonate cemented sandstone that is often seen to protrude prominently from the steep cliffs. The remainder of the Flatsalen Formation is composed of dark mudstone with minor coarsening-upward units (FA 1), grading from intervals of bioturbated open marine mudstone to subordinate hummocky cross-stratified, very fine-grained sandstone beds (FA 2). These coarsening-upward units represent open shelf to offshore transition zone deposits. The uppermost beds of the Flatsalen Formation (Fig. 1c) form a well-defined coarsening-and shallowing-upward succession. The amalgamated hummocky cross-stratified, very fine-grained sandstone beds in the uppermost part of the Flatsalen Formation (FA 2) are lower to middle shoreface deposits.

At Lyngefjellet (Figs. 2b, 3), six facies associations have been defined for the Svenskøya Formation and are presented in Table 1. These associations are also represented on the sedimentological log, Lyngefjellet 12-1 shown in Fig. 4. The Svenskøya Formation is also subdivided into five informal units on the basis of their lithological properties and facies associations (see Figs. 3, 4). Unit 1 consists of beds composed of medium- to coarse-grained sandstone with mud-flake conglomerate (2.5-10.2 m). Unit 2 is mostly composed of immature, fine- to medium-grained sandstones $(10.2-17.7 \mathrm{~m})$. Unit 3 is a fineto medium-grained, mature sandstone with a white to light grey appearance $(17.7-30 \mathrm{~m})$. Unit 4 is a heterolithic succession with mature, fine-grained sandstones and prominent mud-flake conglomerate (30-34.5 m). Unit 5 is a noticeably darker coloured unit composed of mudstone and siltstone with very fine-grained sandstone beds $(34.5-37.5 \mathrm{~m})$.

Description of Unit 1: fluvial channel deposits. The lowermost unit of the Svenskøya Formation is $8.3 \mathrm{~m}$ in thickness (2.5-10.2 $\mathrm{m}$ on the log in Fig. 4). The base of the unit and boundary between Svenskøya and Flatsalen formations is erosive and marks the "Rhaetian Unconformity" in Hopen. The unit is dominated by FA 5 (Table 1) consisting of amalgamated sandstone beds (Fig. 5a). Each bed is seen to scour into the underlying bed, giving a cut-and-fill or channelized appearance. Each channelized structure fines subtly upwards, with a mud-flake conglomerate as a lag deposit, grading into more heterolithic trough and tabular, cross-stratified, fine- to medium-grained sandstone beds in the middle part (Figs. 4, 5b). Asymmetrical ripples cap each bed and coalified plant fragments are abundant throughout the unit.

Interpretation of Unit 1. The presence of a mud-flake conglomerate lag at the base of these cut-and-fill structures, the distinctive lack of burrows or marine fossils, trough cross-stratification, tabular stratification and current ripples indicate rapid deposition of sediment in a high-energy and unidirectional flow regime. Troughs form as three-dimensional dunes migrate, without separation at the dune crests, in unidirectional flow regimes and are common to fluvial deposits (Reading \& Collinson 1996; Fielding 2006). The tabular stratified sandstone beds within this unit are suggested to represent flow in the upper flow regime. These features indicate the presence of small fluvial channels scouring into the underlying formation. Initial high energy resulted in the presence of locally derived mud-flake conglomerates, with the overall fining-upward trend of the succession in Unit 1 suggesting subsequent waning of energy.

The stacked appearance of the amalgamated cut-andfill structures and limited overbank deposits suggests that these have been deposited in low sinuosity channels, probably in a sand-dominated braid plain (Bridge 2006). The deposits found in Unit 1 (in association with the overlying tidal bar deposits, FA 4) correspond well to those expected in the Fluvial Zone of an estuarine depositional model, as described by Dalrymple $\&$ Choi (2007).

It is worth noting, given the uncertainty of dating for the Svenskøya Formation on Hopen, that these mudflakes may also be the cause of discrepancies in palynological dating. This is due to palynological analysis being biased to fine-grained sediments and mud-flakes are likely derived from the older Flatsalen Formation. The fine-grained mud and siltstone deposits at the top of this unit (FA 6) may have been deposited as a mud plug or delta plain deposits, suggesting a brief abandonment of the fluvial system.

Description of Unit 2: tidal bar deposits. Unit 2 is dominated by FA 4 and is $7.5 \mathrm{~m}$ in thickness (10.2-17.7 $\mathrm{m}$ on the log in Fig. 4). The basal cross-stratified, fine-grained sandstone bed is occasionally scouring the fine-grained mud and siltstone beds at the top of Unit 1. Above this 


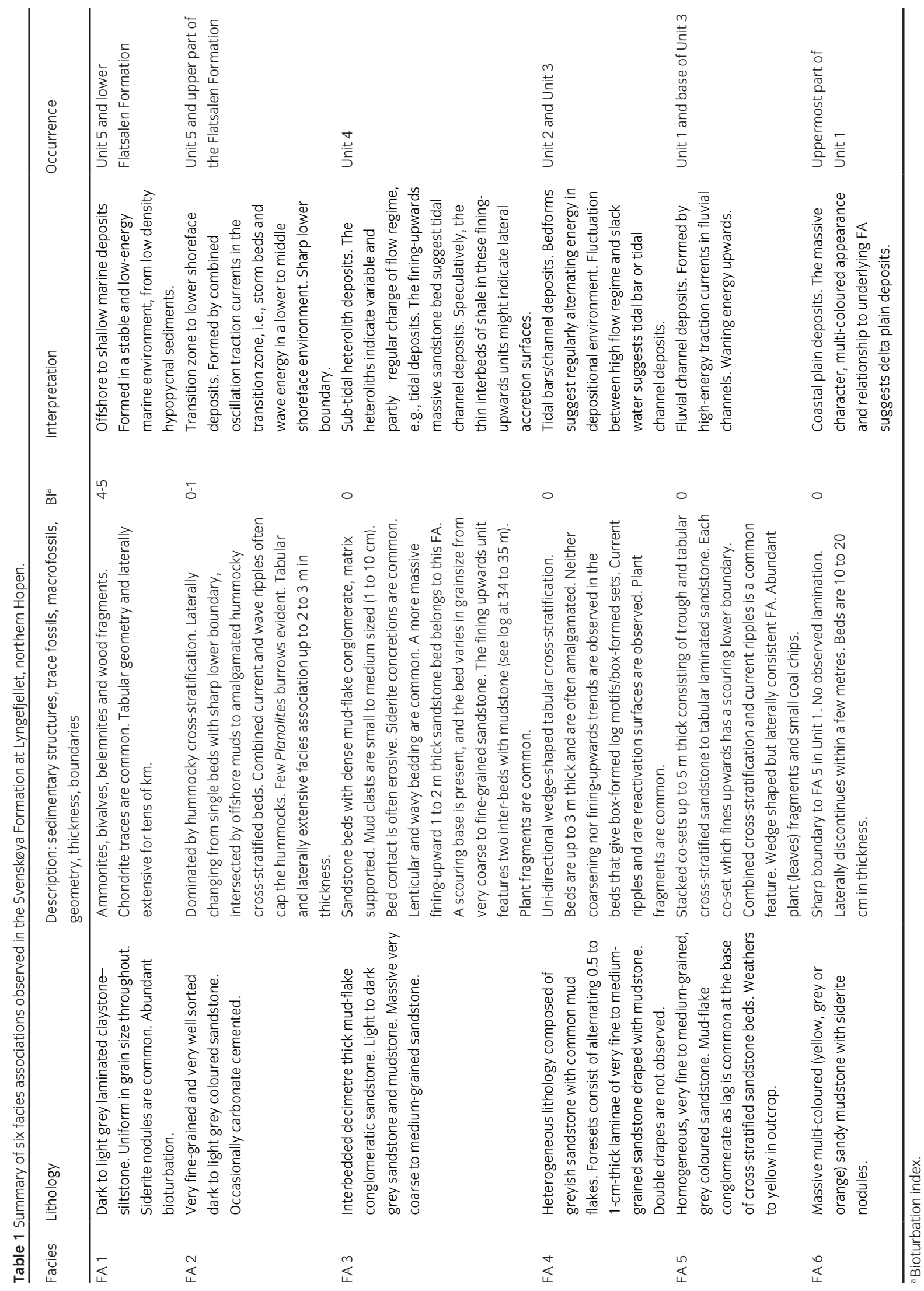




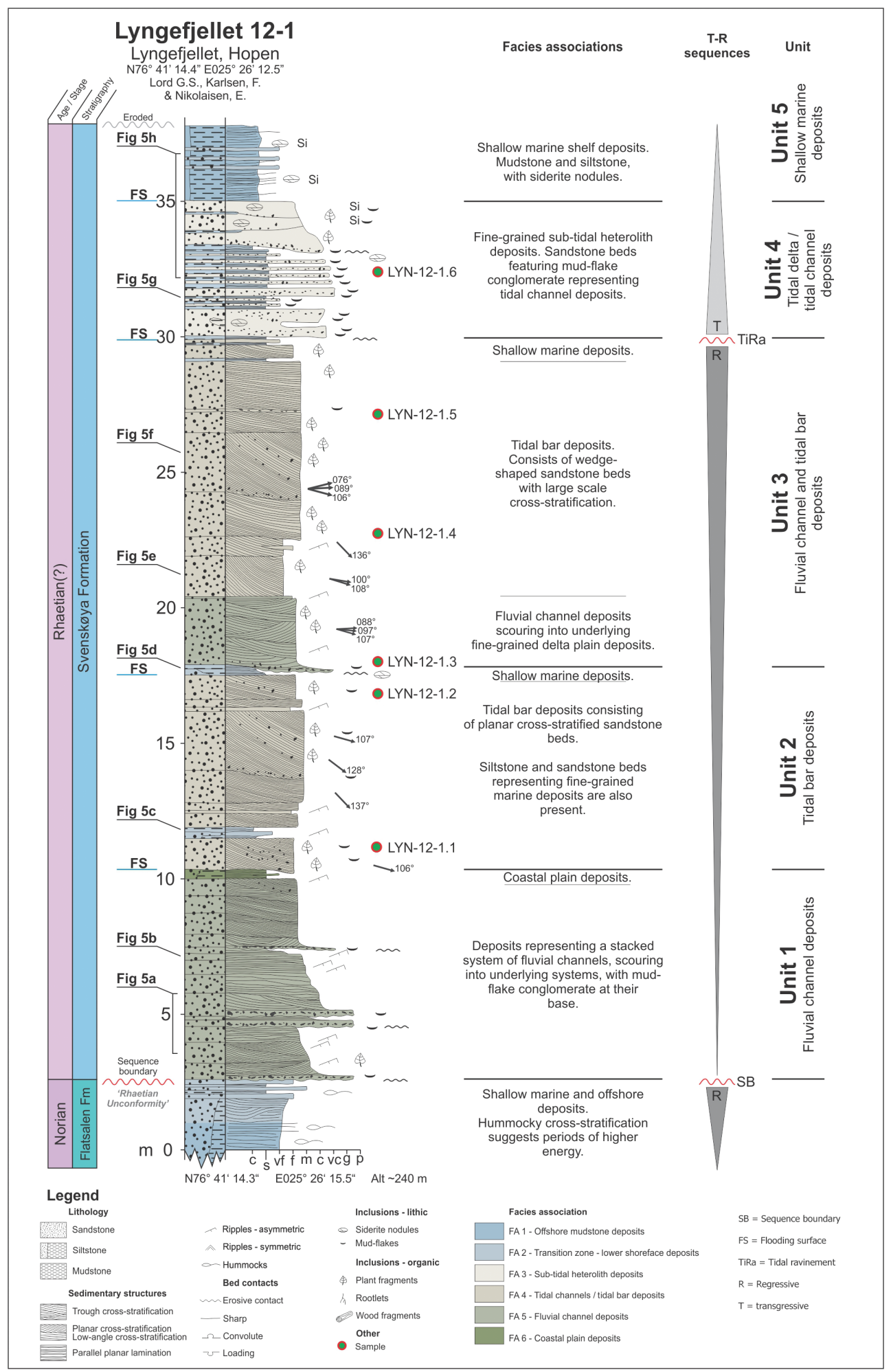

Fig. 4 Log Lyngefjellet 12-1 (Lyn-12-1) recorded of the Svenskøya Formation at the Lyngefjellet locality on Hopen. The lower $8 \mathrm{~m}$ is a composite of data presented by Mørk et al. (1999), with additional observations from later expeditions included. The position of samples recovered for petrographic studies is denoted and a brief description of the sedimentary facies and the unit subdivision is also given. The interpretation of transgressive-regressive sequences of the Flatsalen and Svenskøya formations is also given. 
basal bed, the remaining part of Unit 2 is coarsening upward from mudstone to fine-grained sandstone, followed by a thinner fining-upward part (Fig. 4). Unit 2 is capped by a marine mudstone (FA 1).

The unit is cliff forming and dominated by a thick, tabular, cross-stratified sandstone bed, with mud-drapes on the foresets and scattered mud-flakes (FA 4), giving a heterolithic appearance. The tabular cross-stratified beds range 1-3 $\mathrm{m}$ in thickness and show stacking, with the superimposition of bed-forms. Palaeo-current measurements in this unit suggest migration of foresets to the east and south-east. The basal lower sandstone beds are capped by a ca. 30-cm-thick bed of siltstone (FA 1) with thin rippled sandstone lenses (Fig. 5c). Current ripples are present in the upper part, but wave ripples showing bidirectional flow appear to be absent. No obvious bioturbation has been observed in this unit. Overall, Unit 2 is green/grey in colour and is capped by a thin siltstone bed (Figs. 4, 5d).

Interpretation of Unit 2. The large-scale, tabular, cross-stratified sandstone beds likely represent two-dimensional dunes or bars deposited by unidirectional currents of moderate- to low-energy conditions, as suggested for this type of bedform by Cant $\&$ Walker (1978) and Berné et al. (1994). Scattered mud-flakes on foresets were formed by ripping up thin mud layers during short events of higher flow energy. The mud drapes suggest periodic slack water conditions typical tidal dune migration (Cant \& Walker 1978). Lack of double drapes and trace fossils suggest deposition close to fluvial discharge. The blocky grain size trend also points to a prograding delta front with strong tidal influence.

With the underlying Unit 1 being dominantly fluvial, Unit 2 might be considered to represent the fluvial-tidal transition zone in an estuary as described by Dalrymple \& Choi (2007). The siltstone bed in the uppermost part of the unit (Fig. $5 \mathrm{~d}$ ) is interpreted as representing shallow marine deposits and may indicate the eventual flooding of the delta front. The thin silt interval in the lower part of the unit is also interpreted to be marine in origin.

The erosive basal bed of this unit may represent either a shoreline ravinement unconformity as explained by Embry (2009) or a tidal ravinement. The upper boundary, beneath the overlying marine siltstone bed, is interpreted as representing a minor flooding surface. The relationship of this unit with Unit 1, with the inclusion of a flooding surface at the top, suggests a shift in depositional environment at this point along the palaeo-coastline.
Description of Unit 3: fluvial channel and tidal bar deposits. Unit 3 is $12.3 \mathrm{~m}$ in thickness (17.7-30 $\mathrm{m}$ on the $\log$ in Fig. 4). The boundary between Unit 2 and Unit 3 is erosive. The basal part of the unit consists of a 3-m-thick fining-upward bed, with a mud-flake conglomerate lag scouring the top of Unit 2. This lag is followed by trough cross-stratification fine-grained sandstone beds (FA 5).

Above this bed, a ca. 9-m-thick succession of fine- to medium-grained sandstone beds with large-scale, tabular cross-stratification (FA 4) are present, as in Unit 2. The sandstone beds here are lighter in colour than those in units 1 or 2, being light grey to beige, and appear slightly unconsolidated (Fig. 5e, f). The sandstone beds have weathered along foresets of the cross-stratification into loose sheets. Plant fragments are abundant, whilst mud-flakes are less common in this part of the unit. Palaeo-current measurements suggest dune migration in an east and south-east direction, comparable with measurements recorded in Unit 2. Unit 3 is also capped by a thin siltstone bed (FA 1).

Interpretation of Unit 3. The lower sandstone bed with mud-flake conglomerate, trough cross-stratification, unidirectional current ripples and apparent cut-and-fill structures suggest that these deposits represent fluvial channel fill (FA 5). This may indicate a brief period of scouring, by small distributary channels along a palaeo-coastline, during a local regression probably forced by autogenic factors, such as avulsion of a distributary system within a delta, for example.

The coarsening-upward succession above these fluvial channel deposits features better sorted, tabular, cross-stratified sandstone (FA 4). This succession is interpreted to represent tidal bars as in Unit 2, representing estuarine channel fill. The thin siltstone bed at the top of this unit is interpreted to be shallow marine in origin (FA 1), suggesting the abandonment of a short-lived estuary.

Description of Unit 4: tidal delta/tidal channel deposits. The upper part of the formation is subject to a notable change in its lithological characteristics and facies. Unit 4 (30-37.5 $\mathrm{m}$ on the $\log$ in Fig. 4) consists of a 4.5-m-thick succession of dense mud-flake conglomerate interspersed with thin silt beds (FA 1). The unit overlies the marine shale capping Unit 3, with a sharp and erosive boundary. The lower beds of Unit 4 are abundant in mud-flake conglomerate and medium-grained sandstone, separated by thin beds of mudstone ca. $15 \mathrm{~cm}$ thick (FA 1, Fig. 5g). The sandstone (FA 3) is white to light grey in colour and has a uniform grain size throughout. These sandstones and 

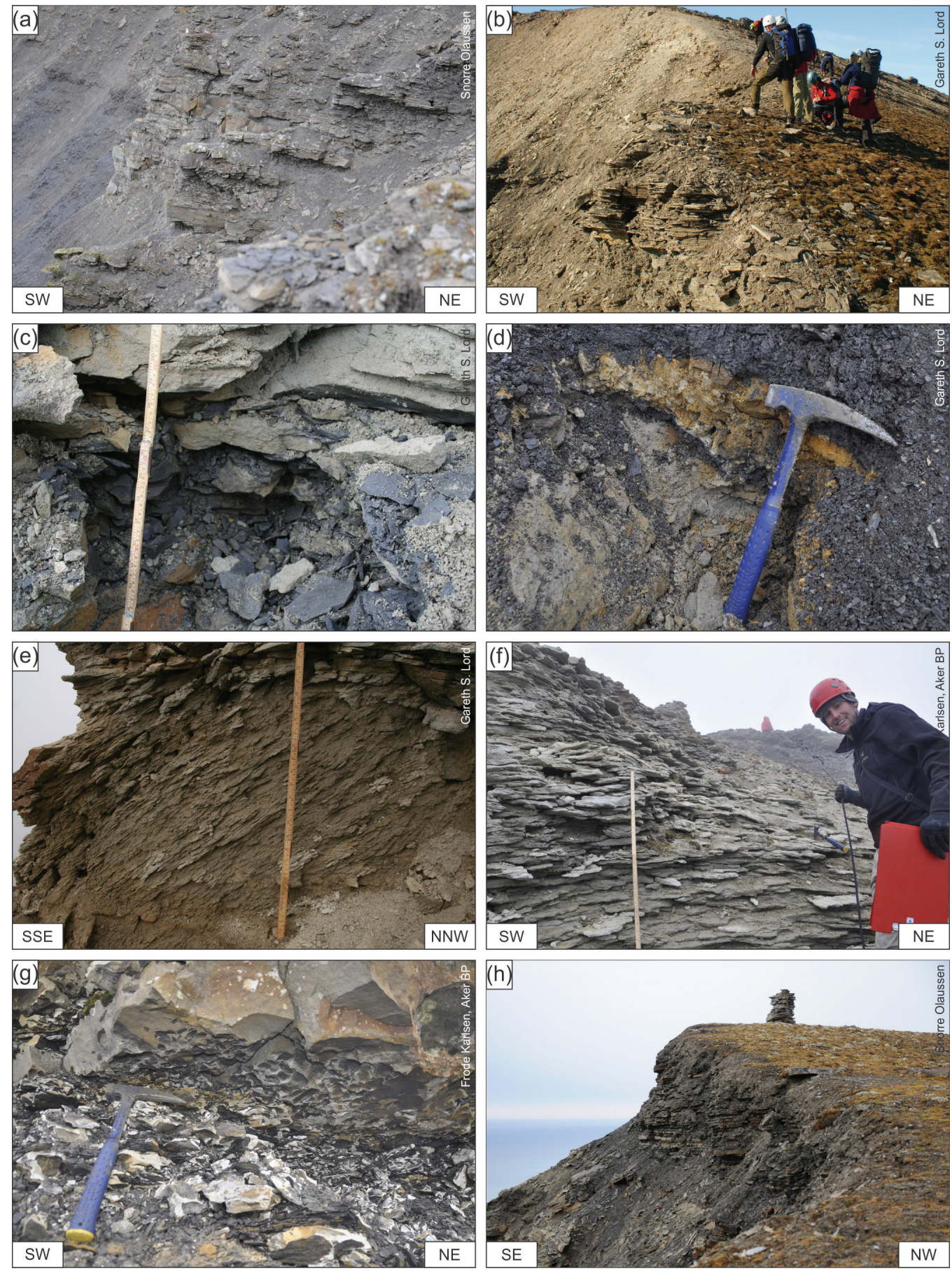

Fig. 5 (a) The lower beds of Unit 1 consisting of mud-flake conglomerate and heterolithic trough cross-stratified sandstones. (b) Tabular sandstone beds at the top of Unit 1. (c) Bed of grey clay-siltstone with thin lenses of orange weathered clay, seen in the lower part of Unit 2. (d) Shallow marine siltstone bed seen at the top of Unit 2. (e) Tabular cross-stratified sandstone bed capped by tabular sandstone beds seen in Unit 3. Note the general trend of palaeo-current measurements being to the east-south-east. (f) Large-scale tabular cross-stratification in the upper part of Unit 3. (g) Lenticular beds of dense mud-flake conglomerate seen in the lower part of Unit 4 . These beds feature faint trough cross-stratification in the sandstone, interpreted as representing lateral accretion surfaces of an estuary. (h) Photograph of the summit of Lyngefjellet with units 4 and 5 showing the transition from heterolithic beds of silt and sandstone with mud-flake conglomerate to the interval of marine shale just below the summit. Note that the position of photographs is also denoted to the left of the log in Fig. 4. 
mud-flake conglomerate beds appear to have a lenticular geometry, which suggests scouring into underlying siltstone beds. Subtle trough cross-stratification and internal scours within the sandstone beds are observed. Laterally, the conglomerate beds appear to pinch out to the south-west on Hopen and vertically the unit fines upwards to siltstone. Lenticular bedding is also observed in the heterolithic middle part of the unit.

Interpretation of Unit 4. The limited exposure severely restricts accurate interpretation of this unit. The scouring characteristics of the sandstone beds in this unit, with faint trough cross-stratification and mud-flake conglomerate, may represent the onset of a new fluvial system or small tidal channels flowing across a subtidal flat (resulting in subtidal heteroliths). The sharp, potentially erosive boundary in the sandstone bed at the base of the unit may represent a tidal ravinement surface; however, no obvious diagnostic tidal features are observed within the unit. The thin interbeds of silt could be argued as representing lateral accretion surfaces within an estuarine channel.

We prefer the interpretation of deposition in a subtidal setting for Unit 4. This interpretation is derived from the overall heterolithic appearance of the unit, in comparison to the underlying succession. The geometries and appearance of apparent channel features in this unit differ significantly from the fluvial channel facies (FA 5) defined in units 1 and 3, and from the tidal bars (FA 4) defined in units 2 and 3. Unit 4 appears to lack any features typically seen in a continental setting, such as roots, paleosols or evidence of overbank deposits.

Description of Unit 5: shallow marine deposits. This unit is a 3-m-thick succession composed of fissile mudstone (FA 1) with thin siltstone and beds of very finegrained sandstone (FA 2). Small siderite concretions with a lenticular geometry appear to be abundant. This unit is found just below the summit of Lyngefjellet (Fig. 5h) and has very limited exposure, the extent of which is shown in Fig. 3.

Interpretation of Unit 5. These uppermost mudstone, siltstone and sandstone beds are interpreted as representing deposition in a shallow marine environment, likely a lagoonal setting. This suggests the presence of a flooding surface at its base (Fig. 4). The presence of overlying marine shales (FA 1) suggests that this part of the Svenskøya Formation was deposited within close proximity to the marine realm. However, as this is the uppermost part of the section, with a considerable portion likely being eroded, the extent or significance of this marine succession is unknown.

\section{Wilhelmøya}

On Wilhelmøya, much of the Svenskøya Formation is poorly exposed because of its unconsolidated nature and scree cover. At Keisarkampen (Figs. 6a, 7), a moderately consolidated exposure is present (Fig. 6b), albeit limited to a small outcrop. The Svenskøya Formation is inferred to have a sharp or erosive contact with the Flatsalen Formation (Figs. 6a, 7) following previous observations (e.g., Worsley 1973). The lowermost exposures of the Svenskøya Formation on Wilhelmøya are composed of fine- to medium-grained sandstones with tabular bedding and tabular cross-stratification (Fig. 6c). Foresets to cross-stratified sandstones in the lower part of the Svenskøya Formation on Keisarkampen trend to the north-east. Field observations suggest that these sandstones represent delta front sediments, with a minor fluvial component. No mud-flakes were noticed; however, plant material is abundant. These deposits likely represent an equivalent to the Late Norian to Rhaetian aged Sjøgrenfjellet Member.

The remainder of the Svenskøya Formation is composed of loose sand or poorly consolidated outcrops of the Late Pliensbachian to Toarcian Mohnhøgda Member. The base is marked by nodules of the Hellwaldfjellet Bed and excavated parts of the succession are seen to consist of relatively massive fine- to medium-grained sandstones. Rootlets and plant fragments are abundant, but sedimentary structures are difficult to distinguish. A bed exhibiting intense bioturbation is present in the upper part and is overlain by a thin siltstone interval. The Mohnhøgda Member on Wilhelmøya most likely consists of shoreface and lower shoreface deposits (Fig. 7).

The Svenskøya Formation is overlain on Wilhelmøya by the Kongsøya Formation, a succession of unconsolidated sandstones deposited in a shoreface environment featuring abundant plant and wood fragments, siderite nodules and intense bioturbation. Above the Kongsøya Formation lies the Bathonian Agardhfjellet Formation, a marine mudstone interval correlative to the Fuglen Formation in the Barents Sea. On Wilhelmøya only a short succession of this formation is present at the summit of Keisarkampen. The presence of abundant phosphatic nodules forming the Brentskardhaugen Bed is seen at the base of the succession, whilst a dolerite sill of the Cretaceous aged Diabasodden Suite forms the summit of the mountain.

\section{Kong Karls Land}

In Kong Karls Land, the boundary between the Flatsalen and Svenskøya formations is covered (Fig. 7) by a ca. 10-m-thick unit of Quaternary to recent strandlines. 

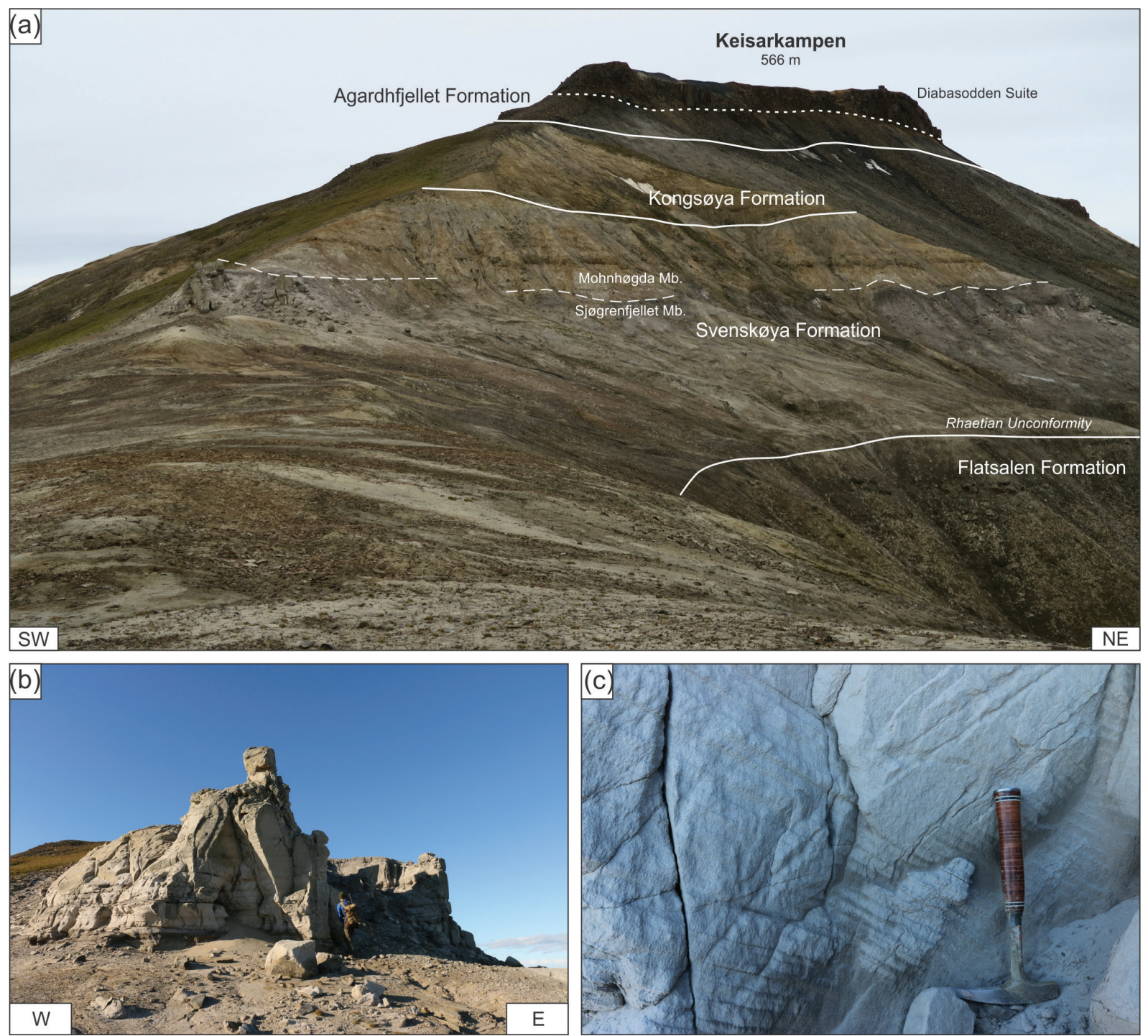

Fig. 6 (a) Photograph of the north-eastern flank of Keisarkampen, Wilhelmøya. Note the poorly exposed Flatsalen, Svenskøya and Kongsøya formations. The upper part of the mountain is formed of a dolerite sill of the Diabasodden Suite intruding into the marine shales of the Late Jurassic aged Agardhfjellet Formation. (b) The primary locality of the Svenskøya Formation on Wilhelmøya where poorly consolidated sandstone beds and loose sand are exposed. (c) Tabular cross-stratified fine- to medium-grained sandstone beds in the Svenskøya Formation on Wilhelmøya. Foresets are composed of finer grains suggesting tidal influence. The sandstones at this locality primarily represent upper shoreface facies deposited in a delta front environment.

An exposed part of the Flatsalen Formation is dated as being early Norian age, whilst the first exposed part of the Svenskøya Formation is possibly late Norian to Rhaetian age (Mørk et al. 1999; Olaussen et al. 2018; Smelror et al. 2018).

The lowermost exposed part of the Svenskøya Formation (Fig. 7) consists of the Rhaetian to Early Pliensbachian aged Sjøgrenfjellet Member and is ca. $160 \mathrm{~m}$ thick. The lower part of the member is composed of a 12-m-thick trough and tabular, cross-stratified, medium-grained sandstone interpreted as fluvial or estuarine channel-fill deposits. The lower part of the Sjøgrenfjellet Member features palaeo-current directions towards the north-east. In terms of facies, the succession shows distinctive similarity with the channelized beds seen in the lower part of the Svenskøya Formation on Hopen.

The remaining part of the Sjøgrenfjellet Member (Fig. 7) comprises heterolithic facies, intersected by channelized beds. Wedge-shaped, tabular, cross-stratified sandstone beds with tidal bundles and reactivation surfaces are common features, both in the channelized and heterolithic beds. The heterolithic and more tabular units are 
composed of 30-50-cm-thick beds with organic-rich claystone at the base and in ascending order passes to lenticular, wavy and, finally, flaser-bedded sandstone suggesting tidal flat deposit, that is, mudflat, mixed-mud sandflat and sandflat, respectively (Reineck \& Singh 1980). The channelized deposits often feature lateral accretion surfaces, which have cleaner sandstones at the base that fines upwards to flaser- and lenticular bedded sandstones that suggest tidal channel fill. Thicker, organic-rich mudstones represent lagoonal or estuarine basin fill.

In one locality, the upper $25 \mathrm{~m}$ of the Sjøgrenfjellet Member has a well-defined coarsening-upward unit, suggested to be a prograding bay-head delta environment. The dominant south-westward palaeo-current trend in most of the formation suggests that provenance of the Sjøgrenfjellet Member is in the north-east. The member is interpreted as having been deposited in an overall estuarine environment, likely similar to environments described in facies studies by Dalrymple \& Choi (2007). The Sjøgrenfjellet Member shows facies similarities with the Tubån and Nordmela formations in the south-western Barents Sea petroleum province (Olaussen et al. 1984; Gjelberg et al. 1987; Henriksen et al. 201 1; Ryseth 2014 ; Olaussen et al. 2018).

There is a sharp boundary between the Sjøgrenfjellet Member and the overlying 45-55-m-thick late Pliensbachian to Toarcian Mohnhøgda Member in the Svenskøya Formation (Fig. 7). The base of the Mohnhøgda Member consists of a 0.5 -m-thick, poorly sorted, quartz gravel bed and shell fragments of ostracods representing a key sequence stratigraphic surface, which is also seen in Spitsbergen (Olaussen et al. 2018; Rismyhr et al. 2018) and the south-western Barents Sea. The lower part of the member consists of hummocky cross-stratified, fine-grained sandstone beds, interbedded with very fine-grained sandstone beds thoroughly burrowed by Ophiomorpha.

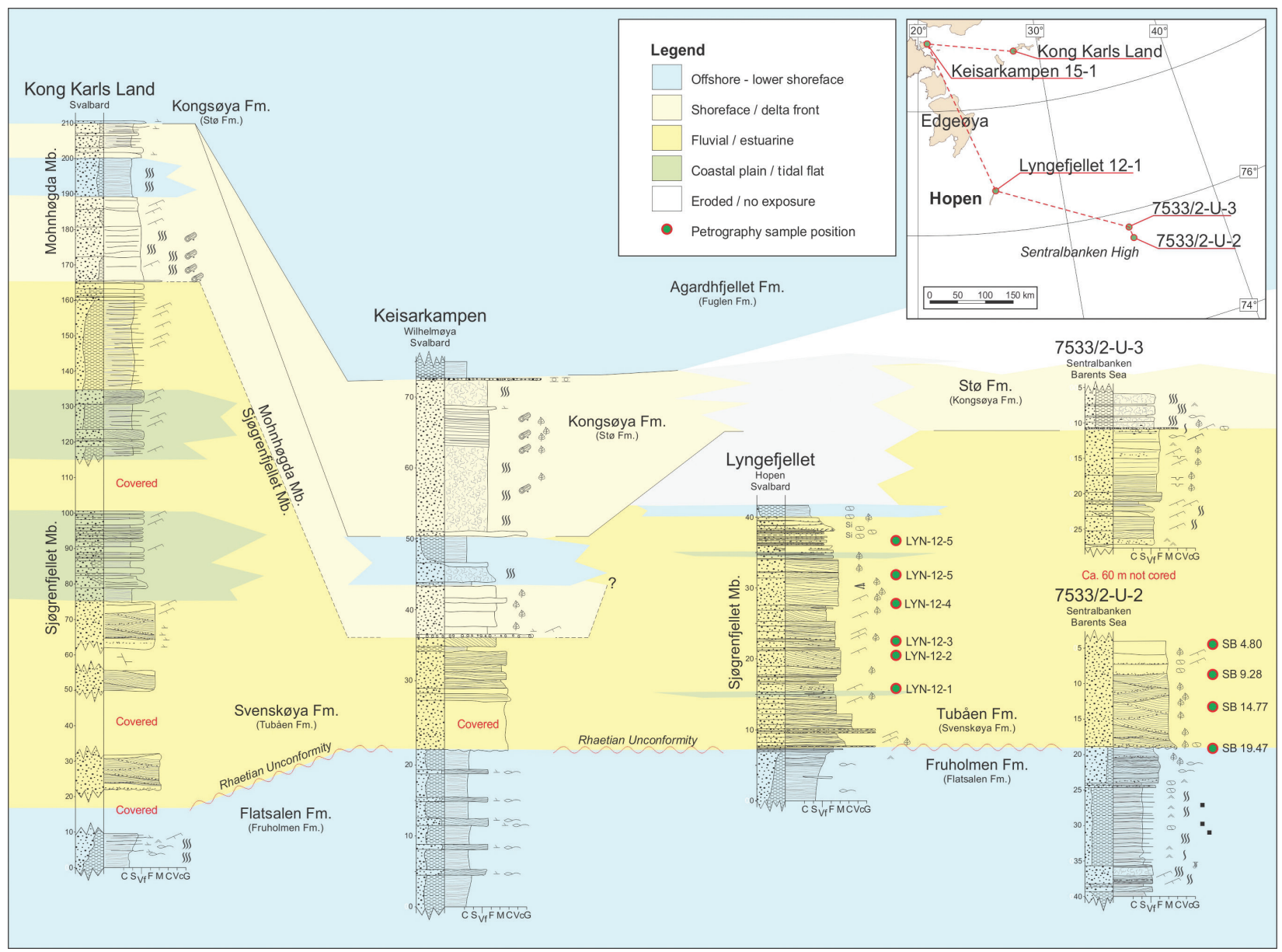

Fig. 7 Correlation diagram of the Svenskøya Formation from locations in Svalbard and the northern Barents Sea, showing the main depositional environments. Note how extensive the erosional "Rhaetian Unconformity" is at the base of the Svenskøya (Tubåen) Formation. Stratigraphic nomenclature for Svalbard and the Barents Sea is combined; comparative units are given in parenthesis. 
This unit represents a shoreface depositional environment (Olaussen et al. 2018).

A heterolithic succession representing offshore or transition zone deposits is seen to overlie the shoreface deposits. This succession is observed to be composed of dark grey to brownish clay and siltstones with an increase in marine palynomorphs (Smelror et al. 2018). In the upper part of the Mohnhøgda Member, a 6-m-thick coarsening-upward unit, with four or five stacked 1-2-m-thick coarsening-upward beds, is seen. These are overlain by channelized cross-stratified sandstone, with a gravel lag along the channel thalweg capping the coarseningupward succession. Lack of burrows in the channel beds with a dominance of bisaccate pollen in the mudstones (Smelror et al. 2018) suggests brackish or freshwater conditions. The coarsening-upward units suggest increased fluvial discharge and likely represent minor mouth bars. The channelized body would then be a distributary channel, in a more fluvial deltaic environment or proximal bay-head delta. The Mohnhøgda Member can be regarded as an analogue to the lower part of the Stø Formation.

The upper boundary of the Svenskøya Formation is marked by the basal lag of the Late Toarcian-Aalenian Kongsøya Formation (Fig. 7). This lag is a thin siderite and mudstone bed, with a 5-cm-thick quartz and chert-rich gravel bed within, containing pieces of wood and siderite pebbles. The Mohnhøgda Member and Kongsøya Formation are near-time equivalent to the lower and middle parts of the Stø Formation in the south-western Barents Sea (Smelror et al. 2018).

\section{Sentralbanken}

The stratigraphic chart in Fig. 2a shows the relationships between onshore stratigraphic units and those found offshore in the Barents Sea. The formations that form the Triassic stratigraphy of Svalbard, which may be correlated throughout the Barents Shelf area, are diachronous (Lundschien et al. 2014). Correlation is therefore on the basis of chronostratigraphic relationships, as opposed to purely lithostratigraphic similarities. Figure 7 presents sections from Svalbard and the correlation of lithological units to the Sentralbanken area. Stratigraphic nomenclature from Svalbard (Mørk et al. 1999) up to the Svenskøya Formation is maintained in the Sentralbanken area (with the exception of the Kongsøya-Stø formations), due to its close proximity to and similarity with eastern and south-eastern Svalbard.

The following explains the relationships between individual stratigraphic units (see Figs. 2a, 7). The Flatsalen Formation extends from the Svalbard area to Sentralbanken and is termed the Fruholmen Formation in the south-western Barents Sea. The Svenskøya Formation is also maintained to Sentralbanken; however, it is termed the Tubåen Formation in the south-western Barents Sea. The Kongsøya Formation is only defined for the Svalbard area at present and is termed the Stø Formation in the Sentralbanken and south-western Barents Sea areas. The Nordmela Formation, present throughout the south-western Barents Sea, is not defined as a formation in itself in Sentralbanken and Svalbard areas but does, however, have facies that correlate well in Kong Karls Land (Gjelberg et al. 1987; Klausen et al. 2017). The surface marking the onset of marine shales in Agardhfjellet Formation throughout Svalbard is traceable into the Sentralbanken area where it is defined as the base of the Fuglen Formation.

Wells 7533/2-U-2 and 2-U-3. In 1998, the Norwegian Petroleum Directorate drilled well 7533/2-U-2 and cored $88 \mathrm{~m}$ of Upper Triassic to Lower Jurassic aged strata in the Sentralbanken area of the Barents Sea (Fig. 7). Overlying the deltaic deposits of the De Geerdalen (Snadd) Formation, $45.6 \mathrm{~m}$ of the Flatsalen (Fruholmen) Formation was also cored. Here, the Flatsalen (Fruhomen) Formation is interpreted as representing shallow marine deposits because of the presence of marine palynomorphs and is interpreted to be correlative to the Flatsalen Formation on Svalbard (Vigran et al. 2014; Paterson \& Mangerud 2015; Paterson et al. 2016; Smelror et al. 2018). Only the uppermost part of the Flatsalen (Fruholmen) Formation was cored in well 7533/2-U-2 (Fig. 7) and this shows striking similarity with exposures of the Flatsalen Formation in Hopen (i.e., offshore burrowed mudstone passing upwards to amalgamated beds with hummocky cross-stratified sandstone).

In well 7533/2-U-2, a 19-m-thick succession of trough cross-stratified sandstone (Fig. 7) is cored and this is interpreted to represent the Svenskøya (Tubåen) Formation in the Sentralbanken area. The boundary between Flatsalen (Fruholmen) and Svenskøya (Tubåen) formations in Sentralbanken shows the same erosional surface as in Hopen.

The basal lag of the Svenskøya (Tubåen) Formation is formed of a calcite cemented bed, containing mud-flakes and siderite fragments. This is followed by ca. $8-10 \mathrm{~m}$ of low-angle cross-stratified, very fine-grained and light grey sandstone. The middle part of the cored succession consists of 5-6 m of fining-upward sandstone beds with intra-formational conglomerates of siltstone and siderite clasts at the base as well as coal fragments and plant debris. The upper part of the core consists of fineto medium-grained sandstone beds that fine upwards to beds of very fine-grained, grey sandstone, which appear massive and without any distinctive lamination. Mudflakes and siltstone clasts are present, but sparse. There are neither macrofossils nor trace fossils observed in the sandstone. The Svenskøya (Tubåen) Formation lacks clear 
marine indicators or trace fossils and here the succession is interpreted as fluvial deposits. The boundary between Flatsalen (Fruholmen) and Svenskøya (Tubåen) formations in Sentralbanken is therefore defined as a subaerial unconformity, like that on Hopen.

Palynological studies of the well indicate the age is the same as the underlying Flatsalen (Fruholmen) Formation (Vigran et al. 2014). The top of the core is close to the seabed and so the total thickness of the formation is not known exactly.

The upper part of the Svenskøya (Tubåen) Formation is seen in core 7533/2-U-3 (Fig. 7). Here it is dated as Jurassic in age and likely correlates to the upper part of the Svenskøya Formation (probably Mohnhøgda Member) in Kong Karls Land (Vigran et al. 2014; Smelror et al. 2018). This core is not discussed in detail further. However, approximately $60-80 \mathrm{~m}$ of the middle part of Svenskøya (Tubåen) Formation is not drilled between the two wells, suggesting the unit is ca. $100 \mathrm{~m}$ thick in the Sentralbanken area.

\section{Petrography and reservoir properties}

Petrographic analysis of samples from the Svenskøya Formation on Hopen (sample positions marked on the Lyngefjellet-12-1 log in Fig. 4) has been included in this study (Fig. 8). Additionally, data from well 7533/2-U-2 in Sentralbanken (Fig. 8) are included, allowing for a comparison of reservoir properties from a structural high in the northern Barents Sea. Samples from the 7533/2-U-2 well are derived from the following core depths in the Svenskøya (Tubåen) Formation: 4.80, 9.28, 14.77 and 19.47 m (Fig. 7).

\section{Permeability}

A sample from Unit 3 on Hopen (25.7 $\mathrm{m}$ on $\log$ Lyngefjellet-12-1) was selected for permeability analysis using standard core plug analysis $(3.8 \mathrm{~cm}$ in diameter and $1 \mathrm{~cm}$ long). The sample is representative of fine- to medium-grained sandstone with mud-flakes and plant material, common to units 2 and 3. The analysis yielded a relatively low permeability value of $0.6 \mathrm{mD}$. This contrasts with the permeability measured in the upper part of the Svenskøya (Tubåen) Formation on the Sentralbanken High, where it is measured to be $145 \mathrm{mD}$ (sandstone from 7533/2-U-2, $5.65 \mathrm{~m}$ depth below the seafloor). Petrographic thin section observations indicate that chemical compaction is the main porosity reducing factor. Another potential permeability reducing factor is the presence of mud-flakes, which are common in the sandstones in the Svenskøya Formation on Hopen.

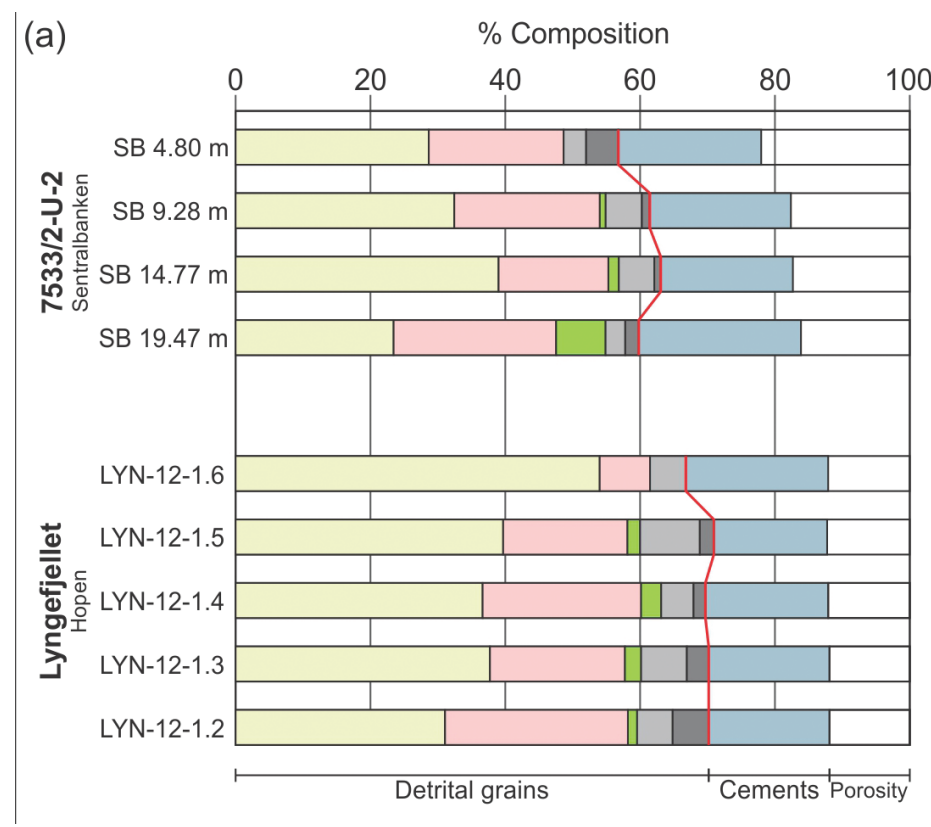

(b)

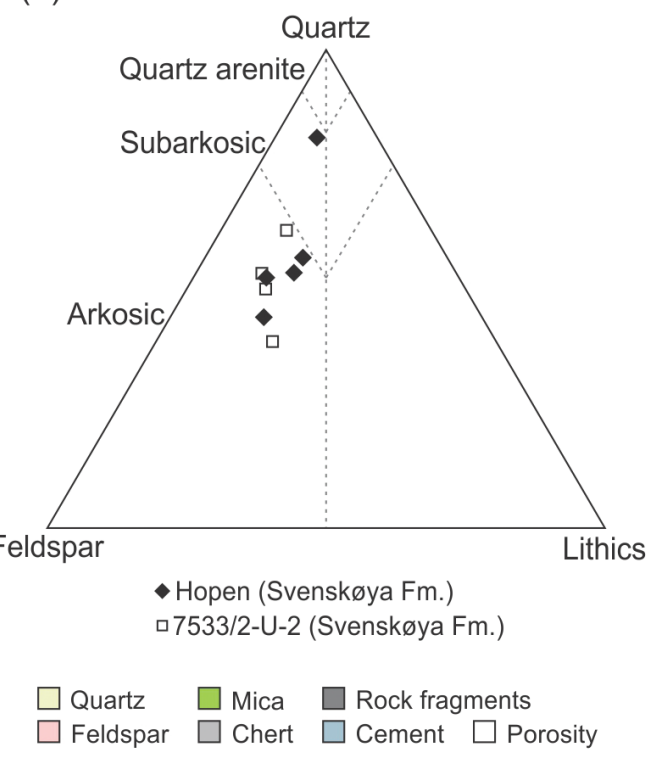

Fig. 8 (a) Sandstone compositions, by percentage, for samples recovered from the Svenskøya Formation at Lyngefjellet and in well 7533/2-U-2 in Sentralbanken. Diagenetic cements are typically quartz, clay minerals \pm carbonate and pyrite (see text). Note the higher inter-granular volume (cements + porosity) in samples from Sentralbanken compared to Hopen, which suggests less compaction has occurred in the Sentralbanken area. (b) Sandstone classification by petrographic modal analysis for samples from Hopen (Lyngefjellet 12-1, Fig. 4) and Sentralbanken. 


\section{Sandstone compositions and impacts of diagenesis: Hopen}

The sandstones from the Lyngefjellet profile (Fig. 4) are fine- to medium-grained with sub-angular to subrounded grains (Fig. 9a, c). Petrographic modal analysis verifies a distinct increase in quartz content, from a relatively immature arkosic mineral composition in the three lower units (units 1, 2 and 3) to the quartz-rich sandstone unit (Unit 4) in the uppermost part of the Svenskøya Formation (Figs. 4, 8a, 9a, b). The detrital grains consist of quartz, feldspar (microcline and plagioclase), minor mica and rock fragments of chert, and locally also chloritized (e.g., volcanic) rock fragments. Accessory heavy minerals observed are zircon, tourmaline, Cr-spinel, rutile, monazite and garnet.

Diagenesis resulted in variable degrees of compaction, quartz cementation, precipitation of clay minerals (including abundant pore-filling kaolinite) and dissolution of labile grains. Petrographic data also show evidence of diagenetic replacement of kaolinite by chlorite, and that chlorite is more abundant in the mineralogically immature sandstones. The content of diagenetic quartz cement has been estimated to be ca. $5-14 \%$ by petrographic modal analysis, with the highest content in the upper sandstone (Unit 4, Lyngefjellet 12-1-1.6).

Secondary dissolution porosity occurs as micro-pores within chert and feldspar grains and as occasional oversized dissolution pores (Fig. 9a, d). The point-counted porosity value is ca. $12 \%$ in all samples. These relatively low values are explained by the combination of diagenetic compaction and formation of abundant porefilling clay minerals (Fig. 9b). Networks with dissolution pores appear pale blue as shown in Figs. 9a, c. Porefilling kaolinite and secondary dissolution porosity in chert grains and feldspar are shown by scanning electron microscopy backscattered electron images of sandstones from Hopen (Fig. 9b, d). However, when considering the micro-porosity associated with clay mineral aggregates and altered labile grains, the total porosity values would be considerably higher, probably approaching $20 \%$.

\section{Sandstone compositions and impacts of diagenesis: Sentralbanken}

Sandstones of the Svenskøya (Tubåen) Formation from Sentralbanken are slightly finer-grained and moderately sorted compared to those from Lyngefjellet on Hopen (Fig. 9e, f). The detrital grain composition consists of quartz, feldspar, mica and rock fragments of chert and volcanic fragments. The sandstones classify as arkosic, overlapping the compositions from Hopen (Fig. 8). Greenish grains interpreted as partly chloritized glauconite may represent intra-basin grains, supporting the marine depositional environment inferred from palynomorphs (Vigran et al. 2014; Paterson \& Mangerud 2015; Paterson et al. 2016). Accessory heavy minerals present include tourmaline, zircon, rutile, Cr-spinel, monazite and garnet, which were also detected in the sediments from Hopen.

Diagenesis involved compaction and alteration of ductile grains (e.g., mica) and precipitation of quartz cement and clay minerals. The amount of quartz cement is similar to the arkosic sandstones at Hopen (5-7\% quartz cement). The authigenic clay minerals appear as pore-filling and grain-replacing kaolinite, illite and chlorite. Carbonate cements include micritic siderite in mud clasts and biotite, and dispersed aggregates of sparitic calcite. The modal porosity values are $17-22 \%$, suggesting a better reservoir quality in the Svenskøya (Tubåen) Formation on Sentralbanken than on Hopen (Fig. 8a). Figure 8 also shows intergranular volumes, supporting that sandstones from Hopen are somewhat more mechanically compacted than at Sentralbanken. This compares to the differences in net erosion values referred to in the Introduction, consistent with the proposed deeper burial history of the Svenskøya Formation on Hopen.

Recently available data from Wilhelmøya (Haile et al. 2018) show limited impacts of chemical compaction (burial diagenesis), explaining the friable sandstone in the Wilhelmøya area (Worsley 1973).

\section{Development of the Svenskøya Formation on Hopen}

Overall, the Svenskøya Formation on Hopen represents a mixture of fluvial channel and tidal bar to estuarine deposits capped by marine shales (Fig. 4). The onset (Unit 1) is marked by an erosive base (i.e., the "Rhaetian unconformity") dominated by small fluvial distributary channels deposited in a coastal environment that are subsequently overlain by two units (units 2 and 3), dominated by a mixture of tidal bar and fluvial deposits. The upper part (Unit 5) suggests a clear change in depositional style from fine-grained sandstone with mud-flake conglomerate to clay and silt. The uppermost beds most likely represent a change to shallow marine conditions.

The lower part of the Svenskøya Formation on Hopen (Unit 1) represents a regressive system of small stacked fluvial channels deposited during rapid deltaic advance. This accounts for the amalgamated channel architecture seen in Unit 1 . The style of deposition in Unit 1 contrasts with the underlying offshore marine to distal shoreline deposits of the Flatsalen Formation, and particularly with the heterolithic, low-angle paralic delta plain 

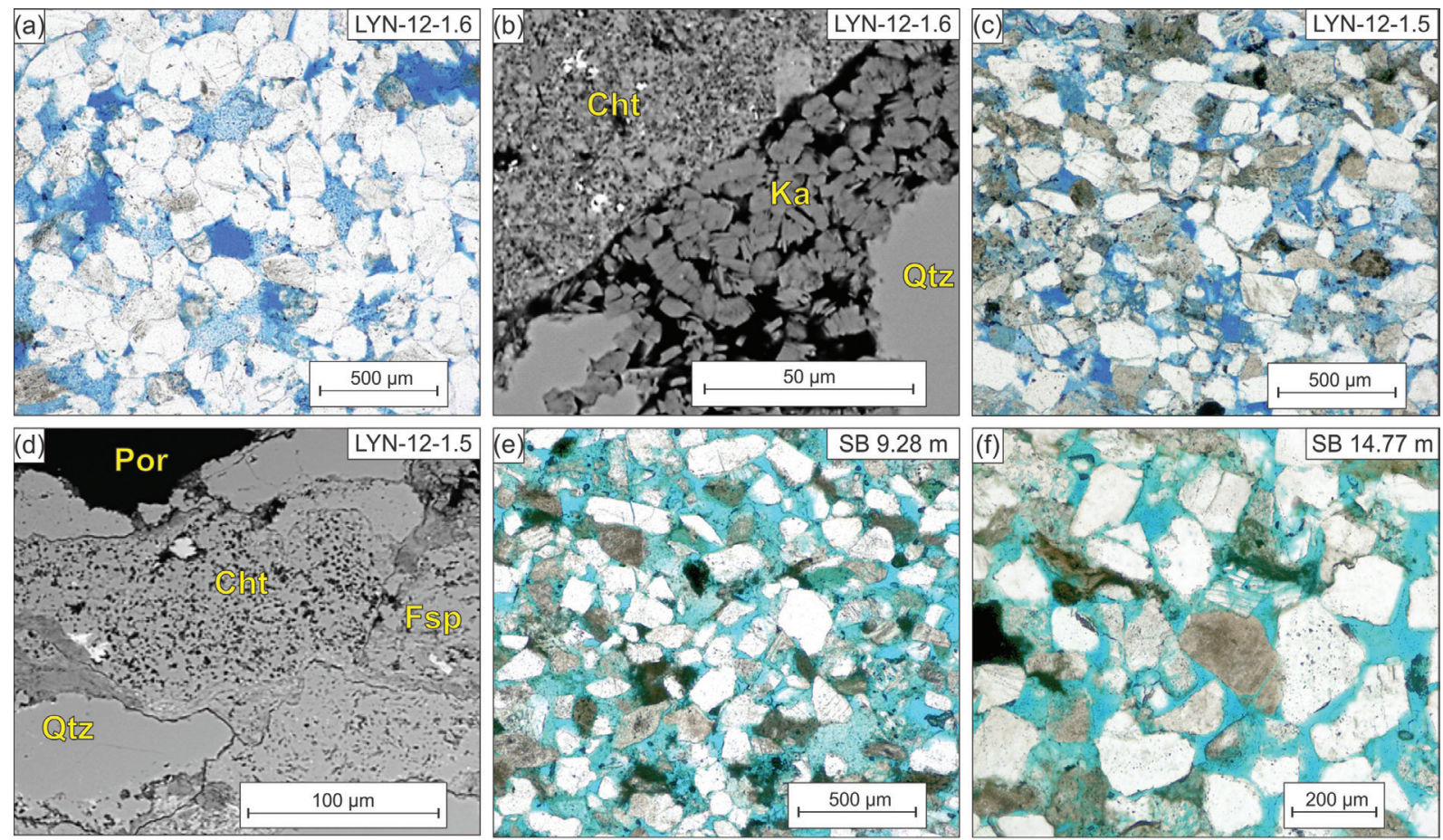

Fig. 9 (a) Optical plain light micrographs from Lyngefjellet 12-1-1.6 recovered from Hopen, showing relatively mature, arkosic sandstone composition (porosity in blue). (b) Backscattered electron micrograph of Lyngefjellet 12-1-1.6, showing pore-filling kaolinite and secondary dissolution porosity in chert grains (porosity in black). (c) Optical plain light micrograph of sample Lyngefjellet 12-1-1.5 recovered from Hopen, showing immature, arkosic sandstone composition (porosity in blue). (d) Backscattered electron micrograph of Lyngefjellet 12-1-1.5, showing pore-filling kaolinite and secondary dissolution porosity in chert grains (porosity in black). (e) Optical plain light micrograph of sample SB $9.28 \mathrm{~m}$ from Sentralbanken (porosity in blue). (f) Optical plain light micrograph of sample SB 9.28 m from Sentralbanken (porosity in blue). The following terms are abbreviated: porosity (Por); quartz (Qtz); feldspar (Fsp); chert (Cht); kaolinite (Ka).

deposits of the underlying Carnian De Geerdalen Formation. The aggressive advance of the system that forms the Svenskøya Formation may be the effect of increased sediment output from a source area coupled with increased denudation rates in the hinterland. Such mechanisms have been observed later in the Jurassic period (Hendriks \& Andriessen 2002; Klausen et al. 2017) and are proposed as being one of the driving agents for the presence of sandstone-rich units in the southern part of the Barents Sea (Klausen et al. 2017).

The development of tidal bar or tidal channel facies in units 2 and 3 suggests a stabilization of the shoreline following the initial regression in Unit 1. This trend may have been forced by autogenic processes occurring higher on the delta plain, resulting in abandonment of that part of the coastline and a local transgression. Alternatively, this may have been caused by allogenic processes, such as relative sea-level rise, or climatic forcing with reduced denudation in the hinterland, for example. However, the exposures on Hopen are not extensive enough to conclude the forcing mechanisms for basin-wide sequences.
South-eastward trending palaeo-current measurements are seen on Wilhelmøya, whilst in Kong Karls Land, palaeo-current measurements for the lower part of the Svenskøya Formation trend to the south-east. This suggests that on Hopen the seawards dipping foresets in the shoreface sandstones indicate a migration of the palaeo-coastline/deltaic advance to the south-east.

The uppermost exposure of the Svenskøya Formation on Hopen (units 4 and 5) is still somewhat enigmatic in terms of its origin, largely because of the limit of exposure. We have used the common mud-flake conglomerates and overall fining upwards of the unit as evidence of subtidal heteroliths, likely representing some form of channel fill, which may have formed in an estuarine environment. The very uppermost exposures forming Unit 5 on Hopen consist of mud and siltstone beds, with thin sandstone beds and siderite concretions. This part of the succession is interpreted to represent shallow marine deposits, suggesting drowning of the subtidal/estuarine system observed in Unit 4. It is unclear whether this flooding surface has any regional significance, as the exposure is limited. 


\section{Regional comparison of sedimentary and stratigraphic properties}

A simplified correlation of stratigraphic and depositional environments from Wilhelmøya and Kong Karls Land in northern Svalbard to Hopen and Sentralbanken is presented in Fig. 7. The Svenskøya Formation can be correlated widely within the eastern and south-eastern area of Svalbard and to the Sentralbanken area of the Barents Sea, where it is equivalent to the Tubåen Formation. This is primarily achieved by identifying the lower regional subaerial unconformity (i.e., the "Rhaetian Unconformity"). At Hopen, Wilhelmøya and Sentralbanken, fluvial, tidal and estuarine deposits dominate the succession. It is impossible to determine the thickness of the formation on Hopen as this is eroded. In Sentralbanken, ca. $100 \mathrm{~m}$ of the unit is present, with only the base (7533/2U-2) and upper part (7533/2-U-3) being cored. On Wilhelmøya, the full thickness of the formation is present $(25 \mathrm{~m})$ and is also interpreted as being composed predominantly of fluvial to shoreface deposits. Shoreface deposits are also observed in the overlying Kongsøya Formation on Wilhelmøya.

A thicker succession is seen in Kong Karls Land (Fig. 7) and deposits of the formation here are determined to represent tidal flat, tidal channel and coastal plain deposits (Mørk et al. 1999; Olaussen et al. 2018). The thinning of the unit is also within regional trends for the Upper Triassic succession in Svalbard, where underlying units are seen to reduce in thickness considerably from east to west (Mørk et al. 1982; Lord et al. 2017).

The palaeo-current measurements from the Svenskøya Formation on Hopen provide evidence for an east and south-eastward migration of a coastline, with foresets dipping seawards as is commonly seen in shoreface deposits. The Rhaetian aged Fruholmen Formation has been regarded to have been sourced from the Novaya Zemlya region (Fleming et al. 2016; Klausen et al. 2017). In wells from the southern Barents Sea, Klausen et al. (2017) relate the influx of mature sandstones in the Fruholmen and Tubåen formations to increased denudation in the southerly source area of Fennoscandia, during the Late Triassic and Early Jurassic epochs (Hendriks $\&$ Andriessen 2002).

Whilst eastern and south-eastern source areas may dominate in the greater Barents Sea area, considerations must be made in Svalbard, given the thickening of the latest Triassic and Early Jurassic aged units from west to east. The Knorringfjellet Formation in western Spitsbergen is a condensed unit of mudstones and sandstones (Mørk et al. 1999; Nagy \& Berge 2008). The formation is notably thinner than its time-equivalent and better developed formations in eastern areas of Spitsbergen and Svalbard. Therefore, it should be considered that in the northern areas of the Barents Shelf and Svalbard, an alternative source area or basin configuration may be controlling sediment dispersal patterns at the end of the Triassic period.

\section{Sequence stratigraphy of the Svenskøya Formation}

The lower boundary surface of the Slottet Bed, at the base of the Flatsalen Formation, represents a subaerial unconformity and this key sequence stratigraphic surface is followed by a mid-Norian aged regional pan-Arctic extensive transgression (Mørk et al. 1999; Worsley 2008; Embry 2011; Klausen \& Mørk 2014; Klausen et al. 2017; Rismyhr et al. 2018). It is a prominent seismic reflector in the Barents Sea and is often defined as the "near base Fruholmen" or the "Norian flooding" in the oil industry. In the platform areas in the Barents Sea and Svalbard, it also marks the slowing down of basin subsidence and climate change (Ryseth 2014; Olaussen et al. 2015).

One of the major sequence stratigraphic boundaries in the Barents Sea and Svalbard is the base of Tubåen and Svenskøya Formation (Gjelberg et al. 1987; Worsley 2008; Olaussen et al. 2018), which has been informally called here the "Rhaetian Unconformity" after Embry (2011). The "Rhaetian Unconformity" has a widespread erosive lower boundary, although not necessarily chronostratigraphic, and occurs throughout the Barents Sea (Gjelberg et al. 1987) and suggests the presence of a high hierarchy sequence boundary (Mørk et al. 1989; Mørk \& Smelror 2001). In the transition from the Norian to Rhaetian ages, the Novaya Zemlya Fold and Thrust Belt underwent significant development (Buiter \& Torsvik 2007; Petrov et al. 2008; Scott et al. 2010; Klausen et al. 2015). The fold and thrust belt probably resulted in the uplift of platform and internal basin highs, west of the main Barents Sea basins (Olaussen $\delta$ Rismyhr 2018).

On Hopen, this boundary is marked by channel deposits at the base of the Svenskøya Formation, where a fluvial system eroded the lower shoreface and offshore transition zone deposits of the Norian aged Flatsalen Formation. This subsequently defines the boundary as a subaerial unconformity. On Hopen, this surface may also represent a significant time gap (Paterson \& Mangerud 2015; Paterson et al. 2016) and marks the onset of a regressive system during the Rhaetian age. It is likely that a period of subaerial exposure occurred prior to the deposition of fluvial channels that form the lower part (Unit 1) of the Svenskøya Formation. An unknown amount of the Flatsalen Formation may well have been eroded by this fluvial system and it is likely that mud-flakes in the 
conglomeratic beds are derived from the Flatsalen Formation. This in turn may also obscure dating by palynology (Niall W. Paterson, pers. comm. 2016), giving older ages as accurate palynological dating is biased to finer-grained material with younger spores having poor preservation potential in sandstone.

The Svenskøya Formation might be regarded as an incised valley fill that could subsequently represent a low-stand system tract in Hopen. The succession represents the rapid deposition of paralic sediments in an overall regressive system. The base of the succession is composed of fluvial braided stream deposits (Unit 1; Fig. 4), sitting atop a regional subaerial unconformity that indicates a rapidly prograding deltaic system. Units 2 and 3 with increasing shoreface deposits represent a change in depositional environment along the coastline, with the formation of a destructive fluvial and wave-dominated delta (Fig. 4). The system is subsequently capped by a clear change in depositional style in its upper part represented by Unit 4 which is composed of tidal deposits probably originating from an estuarine system, above a tidal ravinement surface (Fig. 4). The tidal deposits are subsequently capped by shallow marine mudstone and sandstone deposits (Unit 5). These deposits are only seen as a few metres at the very top of Lyngefjellet and their extent, or significance, cannot be fully determined from such a limited exposure. These mudstone beds may correlate to a similar interval observed on Wilhelmøya; however, this should be regarded as tentative. This trend highlights the paralic nature of the Svenskøya Formation and may represent the close relationship between the ratio of available accommodation space and the rate of sedimentation along a regressive coastline. The increase in marine-influenced facies upwards in the formation may indicate that the available accommodation space increased as the unit was deposited, resulting in the observed facies trend from fluvial to more marineinfluenced environments.

The provenance area and regional palaeogeography for the sandstone beds in the Svenskøya Formation are not addressed here. However, the contrasting palaeo-current measurements and petrography of the Svenskøya Formation on Hopen must be considered, as these are very different from the sandstone units observed in the Carnian De Geerdalen Formation. The east and south-eastward palaeo-current directions measured in the Svenskøya Formation on Hopen are also in contrast to the well-documented north-west-prograding system earlier in the Triassic period (Bergan \& Knarud 1993; Riis et al. 2008; Glørstad-Clark et al. 2010; Anell, Braathen et al. 2014; Anell, Midtkandal et al. 2014;
Klausen et al. 2014; Lundschien et al. 2014). Therefore, the understanding of the regional palaeogeographical development of the Svenskøya Formation is problematic and is an interesting topic for future investigative research.

\section{Implications for northern hydrocarbon resources}

The Norian to Bajocian aged Realgrunnen Subgroup is hitherto the most prolific reservoir unit in the southwestern Barents Sea and potentially in the northern areas as well. Occurrence of bitumen-stained sandstones of the Svenskøya Formation on the east coast of Spitsbergen is consistent with a previously efficient petroleum system (Abay et al. 2017). As in the Barents Sea, the same potential Mesozoic source rocks occur in Svalbard (Mørk \& Bjorøy 1984; Henriksen et al. 201 1; Lundschien et al. 2014).

The underlying Ladinian to Norian aged succession features highly organic marine shales at various stratigraphic intervals. The Anisian and Ladinian aged Botneheia Formation has $1-10 \%$ total organic carbon in Svalbard and 3.2-10.3\% total organic carbon offshore Kong Karls Land (Mørk \& Bjorøy 1984; Leith et al. 1993; Mørk et al. 1999; Lundschien et al. 2014). The marine shales of the Flatsalen Formation (Mørk et al. 1999; Mørk et al. 2013; Klausen \& Mørk 2014; Lord, Solvi, Ask et al. 2014; Lord, Solvi, Klausen et al. 2014) also contain a moderate organic content. Furthermore, the organic rich shale succession of the Agardhfjellet Formation (Leith et al. 1993; Koevoets et al. 2018), the onshore equivalent to the Hekkingen Formation, is also present in northern areas. Thus, three viable source rocks are found in the northern Barents Sea area, in close stratigraphic proximity to the sandstones of the De Geerdalen, Svenskøya and Kongsøya formations.

Lundschien et al. (2014) stated that the Realgrunnen Subgroup is absent throughout large parts of the northern Barents Sea, mostly because of erosion, and where it is present, it is either thin or has an incomplete stratigraphy. Onshore in Spitsbergen, the Wilhelmøya Subgroup is condensed, forming the Knorringfjellet Formation with a vastly different geological development in comparison to its eastern counterpart. In Svalbard, the Svenskøya Formation is $25 \mathrm{~m}$ thick on Wilhelmøya, is minimum 35 m thick on Hopen, is 190 m thick in Kong Karls Land and ca. $100 \mathrm{~m}$ in the Sentralbanken area of the Barents Sea. The average thickness for the Svenskøya Formation is somewhat comparable to the thickness measurements of equivalent units in the southern areas of the Barents Sea, where the Tubåen Formation is typically $40-50 \mathrm{~m}$ (Klausen et al. 2017). 


\section{Conclusions}

The Svenskøya Formation on Hopen can be regarded as a viable analogue to sandstone reservoirs in the northern Barents Sea area. A compelling stratigraphic correlation, sequence stratigraphic similarity and comparable reservoir properties provide a good basis for a unit worthy of further and more detailed observations.

Sedimentological interpretation of the Svenskøya Formation on Hopen classifies the succession as being dominated by fluvial and tidal sediments deposited in a deltaic environment. Palaeo-current data suggest this deltaic system to have been prograding in a south-easterly direction. On Wilhelmøya, fluvial and shoreface deposits are also prevalent in the Svenskøya Formation, with palaeo-currents measured from outcrop, suggesting progradation of the coastline was to the north-east.

In Kong Karls Land, the lower part of the Svenskøya Formation represents a fluvial and estuarine environment, with extensive tidal deposits. The lower part of the formation in Kong Karls Land is similar in facies to those seen on Hopen and the two localities are considered to correlate well.

In the Sentralbanken area, the Svenskøya Formation has facies similar to those observed on Hopen, with fluvial and delta front facies dominating the succession. The Stø Formation is seen to be formed of similar facies as those seen in the Kongsøya Formation on Wilhelmøya, where shoreface facies are also evident (Olaussen et al. 2018). The unit here is expected to be ca. $100 \mathrm{~m}$ in thickness, thinner than the unit in Kong Karls Land.

Facies within the Svenskøya Formation in eastern Svalbard and the northern part of the Barents Sea correlate well with the gross depositional environment for the formation being interpreted as a fluvial and wave-dominated delta. The Svenskøya Formation on Hopen is determined to represent an initial regressive system, with the lower three units of the formation, as defined herein, representing an initial regression at a regional subaerial unconformity (the "Rhaetian Unconformity"). The uppermost part of the formation suggests the onset of a transgressive system with a tidal ravinement surface at its base, culminating in a flooding seen at the uppermost part of the exposure. This regressive-transgressive trend is concluded to be driven by allogenic factors occurring within the deltaic system, resulting in a local transgression of the palaeo-shoreline at Hopen, but is unlikely to be correlated elsewhere.

Sandstones from Hopen and Sentralbanken show an overlapping arkosic composition and include similar types of lithic grains and accessory heavy minerals and mica. The upper sandstone unit on Hopen (Unit 4) differs by a significant increase in mineralogical maturity, which could reflect changes in depositional environments, reworking of older sediments or rejuvenation of a western source area. The mineral proportions have also been somewhat influenced by diagenetic dissolution of feldspar and labile grains.

Lower reservoir quality in Hopen than in Sentralbanken is largely due to differences in diagenesis which caused lower effective porosity at Hopen, which is evidence of more compaction and mineral dissolution, combined with extensive precipitation of pore-filling clay minerals.

\section{Acknowledgements}

The authors thank the Norwegian Petroleum Directorate, SINTEF and Barents Sea Licence partners for the opportunity to join excursions and expeditions that have enabled data collection in remote areas of Svalbard. The Norwegian Petroleum Directorate is further thanked for generously granting access to confidential data, which significantly strengthened this study. Geologists Even Nikolaisen, Turid Haugen (Norwegian University of Science and Technology) and Frode Karlsen (Aker BP ASA) are greatly thanked for their expert help and companionship in the field. The manuscript reviewers-K.J. Krajewski, J.P. Nystuen and R. Olstad-and the Subject Editor for Polar Research, R. Spielhagen, are thanked for their thoroughness and constructive comments throughout the review process.

\section{Disclosure statement}

No conflict of interest was reported by the authors.

\section{Funding}

This research has been funded by several partner organizations. GSL acknowledges the Norwegian Petroleum Directorate and the Arctic Field Grant provided by the Research Council of Norway for funding related to his doctoral research. SO acknowledges the financial assistance of Research Council of Norway grant no. 234152 for the University of Oslo's Triassic North project.

\section{References}

Abay T.B., Karlsen D.A., Lerch B., Olaussen S., Pedersen J.H. \& Backer-Owe K. 2017. Novel proof of migrated petroleum in the Mesozoic strata in Svalbard and detailed organic geochemical characterization-implications for, regional exploration. Journal of Petroleum Geology 40, 5-36, http://dx.doi.org/10.1111/jpg.12662. 
Anell I., Braathen A., Olaussen S. \& Osmundsen P.T. 2013. Evidence of faulting contradicts quiescent northern Barents Shelf during the Triassic. First Break 31, 67-76, http:// dx.doi.org/10.3997/1365-2397.2013017.

Anell I.M., Braathen A. \& Olaussen S. 2014. The TriassicEarly Jurassic of the northern Barents Shelf: a regional understanding of the Longyearbyen $\mathrm{CO}_{2}$ reservoir. Norwegian Journal of Geology 94, 83-98.

Anell I.M., Faleide J.I. \& Braathen A. 2016. Regional tectono-sedimentary development of the highs and basins of the northwestern Barents Shelf. Norwegian Journal of Geology 96, 27-41, http://dx.doi.org/10.17850/njg96-1-04.

Anell I., Midtkandal I. \& Braathen A. 2014. Trajectory analysis and inferences on geometric relationships of an Early Triassic prograding clinoform succession on the northern Barents Shelf. Marine and Petroleum Geology 54, 167-179, http://dx.doi.org/10.1016/j.marpetgeo.2014.03.005.

Bergan M. \& Knarud R. 1993. Apparent changes in clastic mineralogy of the Triassic-Jurassic succession, Norwegian Barents Sea: possible implications for palaeodrainage and subsidence. In T.O. Vorren et al. (eds.): Artic geology and petroleum potential. Pp. 481-493. Amsterdam: Elsevier.

Berné S., Trentesaux A., Stalk A., Missiaen T. \& De Batist M. 1994. Architecture and long term evolution of a tidal sandbank: the Middelkerke Bank (southern North Sea). Marine Geology 121, 57-72, http://dx.doi.org/10.1016/0025-3227(94)90156-2.

Bridge J.S. 2006. Fluvial facies models: recent developments. In H.W. Posamentier \& R.G. Walker (eds.): Facies models revisited. Pp. 85-170. Tulsa: Society for Sedimentary Geology.

Buiter S.J.H. \& Torsvik T.H. 2007. Horizontal movements in the eastern Barents Sea constrained by numerical models and plate reconstructions. Geophysical Journal International 137, 1376-1389, http://dx.doi. org/10.1111/j.1365-246X.2007.03595.

Cant D.J. \& Walker R.G. 1978. Fluvial processes in the sandy braided South Saskatchewan River, Canada. Sedimentology 25, 625-648, http://dx.doi.org/10.1111/j.1365-3091.1978. tb00323.x.

Dallmann W.K. \& Elvevold S. 2015. Bedrock geology. In W.K. Dallmann (ed.): Geoscience atlas of Svalbard. Report Series 148. Pp. 133-174. Tromsø: Norwegian Polar Institute.

Dallmann W.K., Elvevold S., Majka J. \& Piepjohn K. 2015. Tectonics and tectonothermal events. In W.K. Dallmann (ed.): Geoscience atlas of Svalbard. Report Series 148. Pp. 175224. Tromsø: Norwegian Polar Institute.

Dalrymple R.W. \& Choi K. 2007. Morphologic and facies trends through the fluvial-marine transition in tidedominated depositional systems: a schematic framework for environmental and sequence stratigraphic interpretation. Earth Science Reviews 81, 135-174, http://dx.doi. org/10.1111/j.1365-3091.1978.tb00323.x.

Dimakis P., Braathen B.I., Faleide J.I., Elverhøi A. \& Gudlaugsson S.T. 1998. Cenozoic erosion and the preglacial uplift of the Svalbard-Barents Sea region. Tectonophysics 300, 31 1-327, http://dx.doi.org/10.1016/S0040-1951(98)00245-5.

Doré A.G. 1995. Barents sea geology, petroleum resources and economic potential. Arctic 48, 207-221, http://dx.doi. org/10.14430/arcticl243.
Drachev S.S. 2016. Fold belts and sedimentary basins of the Eurasian Arctic. Arktos 2, article no. 21, http://dx.doi. org/10.1007/s41063-015-0014-8.

Embry A. 2011. Petroleum prospectivity of the TriassicJurassic succession of Sverdrup Basin, Canadian Arctic Archipelago. In A.M. Spencer et al. (eds.): Arctic petroleum geology. Pp. 545-558, http://dx.doi.org/10.1144/M35.36. London: The Geological Society.

Embry A.F. 2009. Practical sequence stratigraphy. Calgary: Canadian Society of Petroleum Geologists.

Faleide J.I., Pease V., Curtis M., Klitzke P., Minakov A., Sheck-Wenderoth M., Kostyuchenko S. \& Zayonchek A. 2017. Tectonic implications of the lithospheric structure across the Barents and Kara shelves. In E.P.F. Rose et al. (eds.): Military aspects of geology: fortification, excavation and terrain evaluation. Pp. 285-314. http://dx.doi.org/10.1144/ SP460.18. London: The Geological Society.

Fielding C.R. 2006. Upper flow regime sheets, lenses and scour fills: extending the range of architectural elements for fluvial sediment bodies. Sedimentary Geology 190, 227-240, http://dx.doi.org/10.1016/j.sedgeo.2006.05.009.

Fleming E.J., Flowerdew M.J., Smyth H.R., Scott R.A., Morton A.C., Omma J.E., Frei D. \& Whitehouse M.J. 2016. Provenance of Triassic sandstones on the southwest Barents Shelf and the implication for sediment dispersal patterns in northwest Pangaea. Marine and Petroleum Geology 78, 516-535, http://dx.doi.org/10.1016/j. marpetgeo.2016.10.005.

Flood B., Nagy J. \& Winsnes T.S. 1971. The Triassic succession of Barentsøya, Edgeøya and Hopen (Svalbard). Norsk Polarinstitutt Meddelelser 100. Oslo: Norwegian Polar Institute.

Gjelberg J., Dreyer T., Høie A., Tjelland T. \& Lilleng T. 1987. Late Triassic to Mid Jurassic sandbody development on the Barents andmid-Norwegian shelf. In J. Brooks \& K.W. Glennie(eds.): Petroleum geology of north west Europe. Pp. 1105-1129. London: Graham \& Trotman.

Glørstad-Clark E., Faleide J.I., Lundschien B.A. \& Nystuen J.P. 2010. Triassic seismic sequence stratigraphy and palaeogeography of the western Barents Sea area. Marine and Petroleum Geology 27, 1448-1475, http://dx.doi. org/10.1016/j.marpetgeo.2010.02.008.

Grogan P., Østvedt-Ghazi A-M., Larssen G.B., Fotland B., Nyberg K., Dahlgren S. \& Eidvin T. 1999. Structural elements and petroleum geology of the Norwegian sector of the northern Barents Sea. In A.J. Fleet \& S.A.R. Boldy (eds.): Petroleum geology of northwest Europe: proceedings of the 5th Conference. Vol. 1. Pp. 247-259. London: The Geological Society.

Haile B.G., Czarniecka U., Xi K., Smyrak-Sikora A., Jahren J., Braathen A. \& Hellevang H. 2018. Hydrothermally induced diagenesis: evidence from shallow marine-deltaic sediments, Wilhelmøya, Svalbard. Geoscience Frontiers 10, 629-649, http://dx.doi.org/10.1016/j.gsf.2018.02.015.

Harland W.B. \& Geddes I. 1997. Triassic history. In W.B. Harland (ed.): The geology of Svalbard. Pp. 340-362. London: The Geological Society.

Hendriks, B.W.H. \& Andriessen P.A.M. 2002. Pattern and timing of the post-Caledonian denudation of northern 
Scandinavia constrained by apatite fission track termochronology. In A.G. Dore et al. (eds.): Exhumation of the North Atlantic Margin: timing, mechanisms and implications for petroleum exploration. Pp. 117-137. London: The Geological Society.

Henriksen E., Bjørnseth H.M., Hals K.T., Heide T., Kiryukhina T., Kløvjan O.S., Larssen G.B., Ryseth A.E., Rønning K., Sollid K. \& Stoupakova A. 2011. Uplift and erosion of the greater Barents Sea: impact on prospectivity and petroleum systems. In A.M. Spencer et al. (eds.): Arctic petroleum geology. Pp. 271-281, http://dx.doi.org/10.1144/ M35.17. London: The Geology Society.

Høy T. \& Lundschien B.A. 2011. Triassic deltaic sequences in the northern Barents Sea. In A.M. Spencer et al. (eds.): Arctic petroleum geology. Pp. 249-260, http://dx.doi. org/10.1144/M35.15. London: The Geology Society.

Klausen T.G. \& Mørk A. 2014. Upper Triassic paralic deposits of the De Geerdalen Formation on Hopen: outcrop ana$\log$ to the subsurface Snadd Formation in the Barents Sea. The American Association of Petroleum Geologists Bulletin 98, 1911-1941, http://dx.doi.org/10.1306/02191413064.

Klausen T.G., Müller R., Slama J. \& Helland-Hansen W. 2017. Evidence for Late Triassic provenance areas and Early Jurassic sediment supply turnover in the Barents Sea Basin of northern Pangea. Lithosphere 9, 14-28, http:// dx.doi.org/10.1130/L556.1.

Klausen T.G., Ryseth A.E., Helland-Hansen W., Gawthorpe R. \& Laursen I. 2014. Spatial and temporal changes in geometries of fluvial channel bodies from the Triassic Snadd Formation of offshore Norway. Journal of Sedimentary Research 84, 567-585, http://dx.doi.org/ $10.2110 /$ jsr.2014.47.

Klausen T.G., Ryseth A.E., Helland-Hansen W., Gawthorpe R. \& Laursen I. 2015. Regional development and sequence stratigraphy of the Middle to Late Triassic Snadd Formation, Norwegian Barents Sea. Marine and Petroleum Geology 62, 102-122, http://dx.doi.org/10.1016/j. marpetgeo.2015.02.004.

Koevoets M.J., Hammer Ø., Olaussen S., Senger K. \& Smelror M. 2018. Integrating subsurface and outcrop data of the Middle Jurassic to Lower Cretaceous Agardhfjellet Formation in central Spitsbergen. Norwegian Journal of Geology 98, 1-34, http://dx.doi.org/10.17850/njg98-4-01.

Korčinskaja M.V. 1980. Rannenoriskaja fauna Arhipelaga Svalbard. (Early Norian fauna of the Svalbard Archipelago.) In D.V. Semevskij (ed.): Geologija osadnocnogo cehla Arhipelaga Svalbard. (Geology of the platform cover of the Svalbard Archipelago.) Pp. 30-43. Leningrad: Scientific Research Institute of Arctic Geology.

Launis A., Pott C.P. \& Mørk A. 2014. A glimpse into the Carnian: Late Triassic plant fossils from Hopen, Svalbard. Norwegian Petroleum Directorate Bulletin 11, 129-136.

Leith T.L., Weiss H.M., Mørk A., Århus N., Elvebakk G., Embry A.F., Brooks P.W., Stewart K.R., Pčelina T.M., Bro E.G., Verba M.L., Danyushevskaya A. \& Borisov A.V. 1993. Mesozoic hydrocarbon source-rocks of the Arctic region. In T.O. Vorren et al. (eds.): Artic geology and petroleum potential. Pp. 1-25. Asterdam: Elsevier.
Lord G.S., Johansen S.K., Støen S.J. \& Mørk A. 2017. Facies development of the Late Triassic De Geerdalen Formation on Barentsøya, Wilhelmøya and NE Spitsbergen, Svalbard. Norwegian Journal of Geology 97, 33-62, http://dx.doi. org/10.17850/njg97-1-03.

Lord G.S., Solvi K.H., Ask M., Mørk A., Hounslow M.W. \& Paterson N.W. 2014. The Hopen Member: a new member of the Triassic De Geerdalen Formation, Svalbard. Norwegian Petroleum Directorate Bulletin 11, 81-96.

Lord G.S., Solvi K.H., Klausen T.G. \& Mørk A. 2014. Triassic channel bodies on Hopen, Svalbard: their facies, stratigraphic significance and spatial distribution. Norwegian Petroleum Directorate Bulletin 11, 41-49.

Lundschien B.A., Høy T. \& Mørk A. 2014. Triassic hydrocarbon potential in the northern Barents Sea: integrating Svalbard and stratigraphic core data. Norwegian Petroleum Directorate Bulletin 11, 3-20.

Mørk A. \& Bjorøy M. 1984. Mesozoic source rocks on Svalbard. In A.M. Spencer (ed.): Petroleum geology of the North European Margin. Pp. 371-382. London: Graham \& Trotman.

Mørk A.,Dallmann W.K., Dypvik, H., Johannessen E.P., Larssen G.B., Nagy J., Nøttvedt A., Olaussen S., Pčelina T.M. \& Worsley D. 1999. Mesozoic lithostratigraphy. In W.K. Dallmann (ed.): Lithostratigraphic lexicon of Svalbard, Upper Paleozoic to Quaternary bedrock. Review and recommendations for nomenclature use. Pp. 127-214. Tromsø: Norwegian Polar Institute.

Mørk A., Embry A.F. \& Weitschat W. 1989. Triassic transgressive-regressive cycles in the Sverdrup Basin, Svalbard and the Barents Sea. In J.D. Collinson (ed.): Correlation in hydrocarbon exploration. Pp. 113-130. London: Graham \& Trotman.

Mørk A., Knarud R. \& Worsley D. 1982. Depositional and diagenetic environments of the Triassic and Lower Jurassic succession of Svalbard. In A.F. Embry \& H.R. Balkwill (eds.): Arctic geology and geophysics. Pp. 371-398. Calgary: Canadian Society of Petroleum Geologists.

Mørk A., Lord G.S., Solvi K.H. \& Dallmann W.K. 2013. Geological map of Svalbard 1:100 000, sheet G14G Hopen. Norsk Polarinstitutt Temakart50. Tromsø: Norwegian Polar Institute.

Mørk A. \& Smelror M. 2001. Correlation and non-correlation of high order circum-Arctic Mesozoic sequences. Polarforschung 69, 65-72.

Nasuti A., Ottemöller L., Dallmann W.K., Storheim B.M., Atakan K. \& Olesen O. 2015. Geophysics. In W.K. Dallmann (ed.): Geoscience atlas of Svalbard. Report Series 148. Pp. 225-240. Tromsø: Norwegian Polar Institute.

Nagy J. \& Berge S.H. 2008. Micropalaeontological evidence of brackish water conditions during deposition of the Knorringfjellet Formation, Late Triassic-Early Jurassic, Spitsbergen. Polar Research 27, 413-427, http://dx.doi. org/10.1111/j.1751-8369.2007.00038.x.

NPD 2018. Norwegian Petroleum Directorate FactPages. Accessed on the internet at http://factpages.npd.no/factpages $/$ Default.aspx? culture $=$ en\&nav $1=$ discovery $\quad$ on 11 April 2018.

Olaussen S., Gloppen T.G., Johannessen E. \& Dalland A. 1984. Depositional environment and diagenesis of Jurassic reservoir sandstones in the eastern part of Troms I area. 
In A.M. Spencer (ed.): Petroleum geology of the Northwest European Margin. Pp. 61-80. London: Graham \& Trotman. Olaussen S., Husteli B., Lord G.S., Rismyhr B., Johannessen E.P. \& Mørk A. 2015. The Early Norian transition in Svalbard and the Barents Sea: a record of slowing down of basin subsidence, alteration of facies associations and shift of provenance and climate change. NGF Abstracts and Proceedings of the Geological Society of Norway 2015-4, 39-42, http://dx.doi.org/10.13140/RG.2.1.4376.9206.

Olaussen S., Larssen G.B., Helland-Hansen W., Johannessen E.P., Nøttvedt A., Riis F., Rismyhr B., Smelror M. \& Worsley D. 2018. Mesozoic strata of Kong Karls Land, Svalbard, Norway; a link to the northern Barents Sea basins and platforms. Norwegian Journal of Geology 98, 1-69, http://dx. doi.org/10.17850/njg98-4-06.

Olaussen S. \& Rismyhr B. 2018. Large scale tectonics as controlling factor of the Upper Triassic to Middle Jurassic basin fills in Svalbard and the Barents Sea. Abstract submitted to the International Conference on Arctic Margins VIII, 11 14 June, Stockholm.

Osmundsen P.T., Braathen A., Rød R.S. \& Hynne I. 2014. Styles of normal faulting and fault controlled deposition in the Triassic of Hopen and Edgeøya, Svalbard. Norwegian Petroleum Directorate Bulletin 11, 61-80.

Paterson N.W. \& Mangerud G. 2015. Late Triassic (Carnian-Rhaetian) palynology of Hopen, Svalbard. Review of Paleobotany and Palynology 220, 98-119, http://dx.doi. org/10.1016/j.revpalbo.2015.05.001.

Paterson N.W., Mangerud G., Cetean C.G., Mørk A., Lord G.S., Klausen T.G. \& Mørkved P.T. 2016. A multidisciplinary biofacies characterization of the Late Triassic (late Carnian-Rhaetian) Kapp Toscana Group on Hopen, Arctic Norway. Paleogeography Paleoclimatology Paleoecology 464, 16-42, http://dx.doi.org/10.1016/j.palaeo.2015.10.035

Pčelina T.M. 1972. K voprosu o vozraste osadočnoj tolšči ostrova Nadeždy (Sval'bard). (On the age of the sedimentary succession of the island of Hopen [Svalbard]). In V.N. Sokolov \& N.D. Vasilevskaja (eds.): Mezozoiskie otloženija Sval'barda. (Mesozoic deposits of Svalbard.) Pp. 75-78. Leningrad: NIIGA Publishing.

Petrov G.A., Ronkin Yu L., Maslov A.V., Svyazhina I.A., Rybalka A.V. \& Lepikhina O.P. 2008. Timing of the onset of collision in the central and northern Urals. Doklady Earth Sciences 422, 1050-1055, http://dx.doi.org/10.1134/ S1028334X08070106.

Reading H.G. \& Collinson J.D. 1996. Clastic coasts. In H.G. Reading (ed.): Sedimentary environments: processes, facies and stratigraphy. 3rd edn. Pp. 154-231. Oxford: Blackwell Science.

Reineck H.E. \& Singh I.B. 1980. Depositional sedimentary environments. 2nd edn. Berlin: Springer.

Riis F., Lundschien B.A., Høy T., Mørk A. \& Mørk M.B.E. 2008. Evolution of the Triassic shelf in the northern Barents Sea region. Polar Research 27, 318-338, http://dx.doi. org/10.1111/i.1751-8369.2008.00086.x.

Rismyhr B., Bjærke T., Olaussen S., Mulrooney M.J. \& Senger K. 2018. Facies, palynostratigraphy and sequence stratigraphy of the Wilhelmøya Sugroup (Upper Triassic-Middle
Jurassic) in western central Spitsbergen, Svalbard. Norwegian Journal of Geology 99, http://dx.doi.org/10/17850/njg001.

Ryseth A. 2014. Sedimentation at the Jurassic-Triassic boundary, south-west Barents Sea: indication of climate change. In A.W. Martinius et al. (eds.): From depositional systems to sedimentary successions on the Norwegian Continental Margin. Pp. 187-214, http://dx.doi.org/10.1002/9781118920435. ch9. Oxford: Wiley Blackwell.

Scott R., Howard J., Guo L., Schekoldin R. \& Pease V. 2010. Offset and curvature of the Novaya Zemlya fold-andthrust belt, Arctic Russia. In B.A. Vining \& S.C. Pickering (eds.): Petroleum geology: from mature basins to new frontiers. Proceedings of the 7th Petroleum Conferences. Pp. 645-657. London: The Geological Society.

Senger K. 2017. Integrated thermo-baric modelling of the hydrate stability zone onshore Svalbard, Arctic Norway. Paper presented at the 9th International Conference on Gas Hydrates, 25-30 June, Denver.

Smelror M., Larssen G.B., Olaussen S., Rømuld A. \& Williams R. 2018. Late Triassic to Early Cretaceous palynostratigraphy of Kong Karls Land, Svalbard, Arctic Norway, with correlations to Franz Josef Land, Arctic Russia. Norwegian Journal of Geology 98, 1-31, http://dx.doi.org/10.17850/njg004.

Smith D.G. 1974. Late Triassic pollen and spores from the Kapp Toscana Formation, Hopen, Svalbard-a preliminary account. Review of Palaeobotany and Palynology 17, 175-178, http://dx.doi.org/10.1016/0034-6667(74)90098-0.

Smith D.G., Harland W.B. \& Hughes N.F. 1975. Geology of Hopen, Svalbard. Geological Magazine 112, 1-23.

Smith D.G., Harland W.B., Hughes N.F. \& Pickton C.A.G. 1976. The geology of Kong Karls Land, Svalbard. Geological Magazine 113, 193-304.

Solvi K.H. 2013.Visualize and interpret the geometry, heterogeneity and lateral continuation of channel bodies in the De Geerdalen Formation at Hopen. Master's thesis, Norwegian University of Science and Technology, Trondheim.

Throndsen T. 1982. Vitrinite reflectance of coals and dispersed organic matter in Tertiary deposits in the Advendalen area, Svalbard Polar Research 1(2), 77-91, http:// dx.doi.org/10.3402/polar.v1982i2.7005.

Tozer E.T. \& Parker J.R. 1968. Notes on the Triassic biostratigraphy of Svalbard. Geological Magazine 105, 526-542. http://dx.doi.org/10.1017/S0016756800055886.

Vigran J.O., Mangerud G., Mørk A., Worsley D. \& Hochuli P.A. 2014. Palynology and geology of the Triassic succession of Svalbard and the Barents Sea. Geological Survey of Norway, Special Publication 14. Trondheim: Geological Survey of Norway.

Worsley D. 1973. The Wilhelmøya Formation-a new lithostratigraphic unit from the Mesozoic of eastern Svalbard. Norsk Polarinstitutt Arbok 1971, 7-16.

Worsley D. 2008. The post-Caledonian development of Svalbard and the Western Barents Sea. Polar Research 27, 318-338, http://dx.doi.org/10.1111/j.1751-8369.2008. 00085.x.

Worsley D., Johansen R. \& Kristensen S.E. 1988. The Mesozoic and Cenozoic successions of Tromsøflaket. Norwegian Petroleum Directorate Bulletin 4, 42-65. 